\title{
ANALISIS JEJARING SOSIAL DALAM MENGETAHUI KEKUATAN DIPLOMASI DIGITAL INDONESIA DI KAWASAN AMERIKA SELATAN
}

\author{
Dinanda Diadeska Diara \\ Universitas Paramadina Jakarta, Indonesia \\ Email: deskaliem@gmail.com
}

\begin{tabular}{|c|c|}
\hline \multicolumn{2}{|c|}{ Artikel info } \\
\hline \multicolumn{2}{|c|}{ Artikel history } \\
\hline Diterima & $20-11-2020$ \\
\hline Direvisi & : $12-12-2020$ \\
\hline Disetujui & :19-12-2020 \\
\hline
\end{tabular}

Kata kunci: Diplomasi

Digital, Ruang Siber, Analisis Jejaring Sosial

Keywords: Digital Diplomacy, Cyberspace, Social Network Analysis

\begin{abstract}
Abstrak
Di era kontemporer ini diplomasi tidak hanya dilakukan antar negara saja, tapi juga melibatkan publik sebagai tujuan maupun peserta aktif dalam diplomasi. Proses diplomasi yang melibatkan aktor aktif negara maupun non negara dalam memberikan pemahaman dan membentuk persepsi masyarakat domestik maupun internasional tentang identitas, nilai-nilai ataupun kebijakan negara, disebut diplomasi publik. Dalam melakukan diplomasi publik, tiap aktor harus mengikuti perkembangan zaman termasuk menggunakan inovasi berbasis teknologi digital. Penggunaan teknologi digital untuk mencapai tujuan diplomasi publik inilah yang dinamakan sebagai diplomasi digital. Penelitian ini bertujuan untuk menganalisa kekuatan diplomasi digital yang terjalin antara Indonesia dengan negaranegara di kawasan Amerika Selatan dengan menggunakan metode Social Network Analysis dan pendekatan kuantitatif dimana tools yang digunakan adalah Gephi 0.9.2 dan pengolahan data melalui microsoft excel 2016..
\end{abstract}

\begin{abstract}
In this contemporary era, diplomacy is not the only

one that carried out between the countries, but also involves the public as an objective and an active participant. The diplomacy process that involves active state and non-state actors in providing understanding and shaping the perception of the domestic and international community about the identity, values or state policies, is called as public diplomacy. In carrying out public diplomacy, each actor must keep up with the times including the usage of digital technology-based and innovations. The usage of digital technology, overall to achieve the goals of public diplomacy which is known as digital diplomacy. The author aims to analyze the strength of digital diplomacy that exists in between Indonesia and countries in the South of American region using the Social Network Analysis method and a quantitative approach and also the tools which used are Gephi 0.9.2 and data processing through microsoft excel 2016
\end{abstract}

Koresponden author: Dinanda Diadeska Diara Email: deskaliem@gmail.com artikel dengan akses terbuka dibawah lisensi

CC BY SA 2021

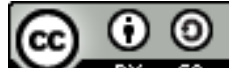

\section{Pendahuluan}

Sesuai tujuan diplomasi publik, diplomasi digital juga berusaha memenangkan hati dan pikiran masyarakat, dengan cara ini kepentingan negara akan lebih mudah tercapai. 
Seperti halnya menyebarkan ideologi atau nilai-nilai tertentu, mendukung perdagangan dan kerjasama internasional, memudahkan penyelesaian konflik, maupun mendapatkan dukungan dalam politik internasional. Dari sisi kebijakan, diplomasi digital dapat membawa dampak besar bagi kebijakan luar negeri suatu negara. Pertama dalam bidang pelayanan, teknologi informasi dan komunikasi memungkinkan aktor negara bekerja lebih efektif, serta efisien. Dengan begitu aktivitas pelayanan warga negara maupun warga negara asing baik di dalam maupun di luar negeri, seperti urusan visa, atau passport, dapat berjalan lebih efisien. Komunikasi di dunia maya antar manusia di seluruh dunia memungkinkan terjadinya pertukaran ide atau pemikiran yang dapat membentuk sebuah persepsi. Persepsi ini penting untuk membentuk citra suatu negara. Kemudian jaringan, masyarakat digital seringkali memiliki keterhubungan tertentu, seperti google, wikipedia, instagram, twitter, ataupun facebook. Ini tentunya mempermudah pembuat kebijakan luar negeri dalam membuat kebijakan luar negeri tentang bagaimana merespon maupun memutuskan suatu keputusan melalui isu-isu yang didiskusikan dalam jaringan-jaringan . Jaringan-jaringan teresebut lalu dimaanfaatkan oleh pihak yang berkepentingan terutama pemerintah untuk mengambil atau menyebarkan informasi, seperti membaca big data tentang opini publik dan beriteraksi dengan masyarakat dunia melalui twitter. Diplomasi digital tentunya dapat menjadi strategi baru antar aktor negara maupun lintas negara seperti Government, NGO, Mass Media dan lain sebagainya. Dengan adanya diplomasi digital, diplomasi dapat berjalan dengan lebih inklusif, transparant, partisipatif, dan bersahabat. Namun, ada juga kelemahan dari diplomasi digital, yakni sulitnya mengontrol aktor yang terlibat karena jejaring yang ada serta kemungkinan peretasan terhadap informasi diplomatik rahasia. Oleh karena itu, perlu digaris bawahi bahwa diplomasi digital bukan merupakan pengganti diplomasi konvensional. Keduanya ada untuk saling melengkapi dengan kelebihan dan kekurangan masing-masing. Sehingga dapat berjalan sinergis demi mencapai kepentingan nasional dan perdamaian dunia.

\section{Masyarakat Digital}

Secara konseptual, masyarakat digital sangat terkait dengan masyarakat jejaring atau network society. Masyarakat jejaring ialah masyarakat yang struktur sosialnya jaringan dengan teknologi mikro-elektronik berbasis informasi digital dan teknologi komunikasi. Teknologi digital bertujuan meningkatkan efisiensi dan produktivitas. Ada tiga pilar utama dalam masyarakat digital. Pertama digital citizenship yakni bagaimana perangkat digital digunakan dalam pelayanan publik dan keterlibatan masyarakat dalam pemerintahan. Kedua ialah digital life-style, yakni penggunaan teknologi digital dalam kehidupan sehari-hari, seperti twitter. Ketiga ialah digital commerce, yaitu bagaimana teknologi digital digunakan 
untuk perekonomian khususnya perdagangan. Twitter merupakan salah satu aplikasi berbasis web dan mobile yang paling banyak diminati oleh warga dunia terutama di era masyarakat digital seperti sekarang. Twitter setidaknya pernah menempati peringkat dua terbesar di dunia dalam kategori social media yang paling banyak diminati (Eric, 2011). Menyadari betapa pentingnya digital diplomacy terutama dalam masa pandemi seperti sekarang, penelitian ini bertujuan dalam memahami lebih lanjut tentang kekuatan diplomasi digital yang terjalin antara Indonesia dan negara-negara di kawasan Amerika Selatan yakni Argentina, Paraguay, Bolivia, Peru, Brazil, Chile, Kolombia, Ekuador, French Guiana, Guyana, dan Venezuela melalui analisa pada media jejaring sosial Twitter, menggunakan tools penganalisaan data yakni Gephi 0.9.2 dan microsoft excel 2016 serta melalui tentunya metode Social Network Analysis dan pendekatan kuantitatif.

\section{Diplomasi Digital}

Secara singkat, diplomasi digital dapat diartikan sebagai penggunaan instrumeninstrumen digital dan teknologi informasi dalam mencapai tujuan, yang dalam hal ini, merupakan kepentingan nasional. Dengan adanya digital diplomacy maka terbentuknya borderless dalam ruang lingkup relasi interaksi aktor dunia, yang dalam hal ini, tentunya aktor dunia bukan hanya pemerintah. Dalam penelitian ini, penulis mengkategorikannya dalam beberapa cluster atau aktor yang terlibat, yakni government, NGO, mass media serta other dimana other disini adalah masyarakat digital. Teknologi dan Informasi merupakan bagian terpenting di era globalisasi seperti sekarang, serta ilmu pengetahuan, keyakinan, dan gagasan merupakan alat utama bagi para aktor negara dalam upaya dan usaha untuk mencapai tujuannya yakni kepentingan nasional (David, 2003).

\section{Soft Diplomacy}

Alat diplomasi Indonesia untuk mempromosikan Indonesia, tidak hanya Iindonesia sebagai suatu negara, tetapi nilai-nilai budaya, pendidikan, musik, seni, dan lain sebagainya, inilah yang dinamakan sebagai soft diplomacy. Dalam kaitannya dengan penelitian ini, soft diplomacy tentunya erat kaitannya dengan digital diplomacy. Seperti halnya bagaimana Korea Selatan mempromosikan seni dan budayanya, bahasa, musik, pendidikan dan lain sebagainya melalui soft diplomacy dimana media promosinya ialah social media seperti youtube, facebook, twitter, dan instagram. Adanya soft diplomacy tentunya akan meningkatkan kekuatan diplomasi digital suatu negara (Cull \& J, 2009).

\section{Level of Influence}

Penulis menggunakan istilah Level of Influence dalam penelitian ini menjelaskan degree yang ada pada data dimana didapat dari hasil analisa jejaring sosial melalui aplikasi Gephi 0.9.2, data yang didapat dengan cara grabbing data API Twitter. Degree disini merupakan banyaknya suatu node atau sebuah user ID twitter (aktor digital) di mention atau melakukan mention terhadap nodes lainnya. Singkatnya, seberapa besarkah kemampuan suatu node dalam mempengaruhi masyarakat digital dilihat dari tingkat influence. Dalam hal ini, parties atau countries yang disajikan ialah Indonesia dan negara-negara di kawasan Amerika Serikat.

\section{Level of Interest}

Penulis menggunakan istilah Level of Interest dalam penelitian ini menjelaskan page rank yang ada pada data dimana didapat dari hasil analisa jejaring sosial melalui Gephi 0.9.2, data yang didapat melalui grabbing data API Twitter. Page rank disini merupakan 
banyaknya suatu node atau sebuah user ID twitter (aktor digital) di retweet atau melakukan retweet terhadap nodes lainnya. Singkatnya, seberapa besarkah kemampuan suatu node dalam mempengaruhi masyarakat digital dilihat dari tingkat interest. Dalam hal ini, parties atau countries yang disajikan ialah Indonesia dan negara-negara di kawasan Amerika Serikat.

\section{Digital Diplomacy Index}

Penulis menggunakan istilah Digital diplomacy index dalam penelitian ini menjelaskan value yang didapat dari pembagian antara degree (Level of influence) dan page rank (Level of interest) yang ada pada data dimana didapat dari hasil analisa jejaring sosial Gephi 0.9.2 yang didapat melalui grabbing data API Twitter. Digital Diplomacy Index merupakan satuan perhitungan yang mengindikasikan tingkat pengaruh dan kepentingan suatu aktor dalam jejaring diplomasi digital. Jejaring diplomasi digital yang dimaksud dalam tugas ini, merupakan jejaring akun twitter dalam suatu hubungan diplomasi tertentu. Singkatnya, perbandingan kekuatan diplomasi digital yang terjadi pada parties atau countries yang dapat dibuktikan melalui scoring. Dalam hal ini, parties atau countries yang disajikan ialah Indonesia dan negara-negara di kawasan Amerika Serikat.

\section{Metode Penelitian}

Dalam penelitian ini, penulis menggunakan metode pendekatan kuantitatif perbandingan data yang didapat melalui grabbing data twitter guna menganalisa kekuatan diplomasi digital antara Indonesia dan negara-negara di kawasan Amerika Selatan menggunakan tools berupa aplikasi Gephi 0.9.2 dan microsoft excel 2016. Serta penggunaan graf sebagai teori, dimana graf disini dapat menjadi acuan penting dalam melihat relasi yang terbentuk antara masyarakat digital lintas negara dan kaitannya dengan diplomasi digital antara Indonesia dan Amerika Selatan. Graf tersebut berisikan nodes dimana nodes disini merupakan aktor atau pihak-pihak yang terlibat, serta edges yang merepresentasikan atau menggambarkan relasi yang terjalin antara nodes tersebut, hal ini dinamakan socio-grams (Haythornthwaite, 1996).

\section{Hasil dan Pembahasan}

\section{Argentina, Paraguay dan Uruguay}

a. Akun Twitter Resmi

$\rightarrow$ @KBRIBuenosAires (Akun twitter resmi Kedutaan Besar Indonesia di Argentina, Uruguay dan Paraguay) dan @CancilleriaARG (Akun twitter resmi Kedutaan Besar Argentina di Indonesia).

b. Analisa Data

Untuk dapat melakukan analisa ini, penulis melakukan grabbing data melalui microsoft excel 2016, lalu setelah data didapat dari kedua akun twitter resmi tersebut, data selanjutnya di merge atau combine masih dalam microsoft excel 2016, kemudian hapus kolom selain target, source dan weight, pastikan jika ada baris dari kolom weight yang bernilai 0, ubah terlebih dahulu menjadi 1. Kemudian save as dengan format xls. Kemudian buka Gephi 0.9.2, pertama-tama, jalankan plugins yang ada pada tab overview kemudian masuk ke tab data laboratory, klik import spreadsheet lalu pilih file excel yang sudah kita dapat dari hasil grabbing data yang dilakukan, lalu jika berhasil, copy data to 
other column dan pilih ID, kemudian Label. Setelah itu, pindah lagi ke tab overview. Pada bagian appearance untuk color, pilih ranking berdasarkan degree serta untuk size, pilih ranking berdasarkan PageRank. Kemudian apply. Selanjutnya, pada kolom layout, pilih circle park layout. Juga masukan credentials pada bagian tab twitter streaming importer.

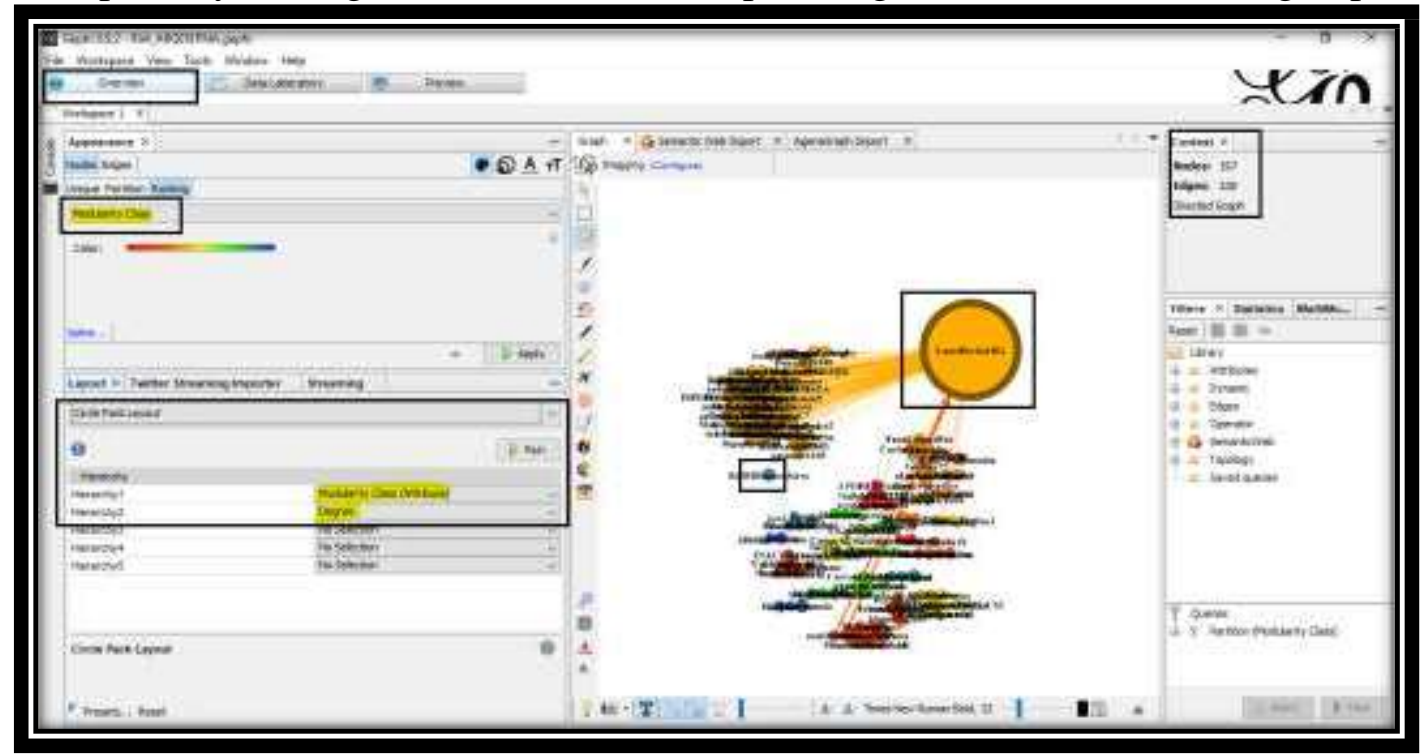

Gambar 1 Gephi Kekuatan Diplomasi Digital antara Indonesia dan Argentina (serta

Paraguay dan Uruguay) dengan circle park layout

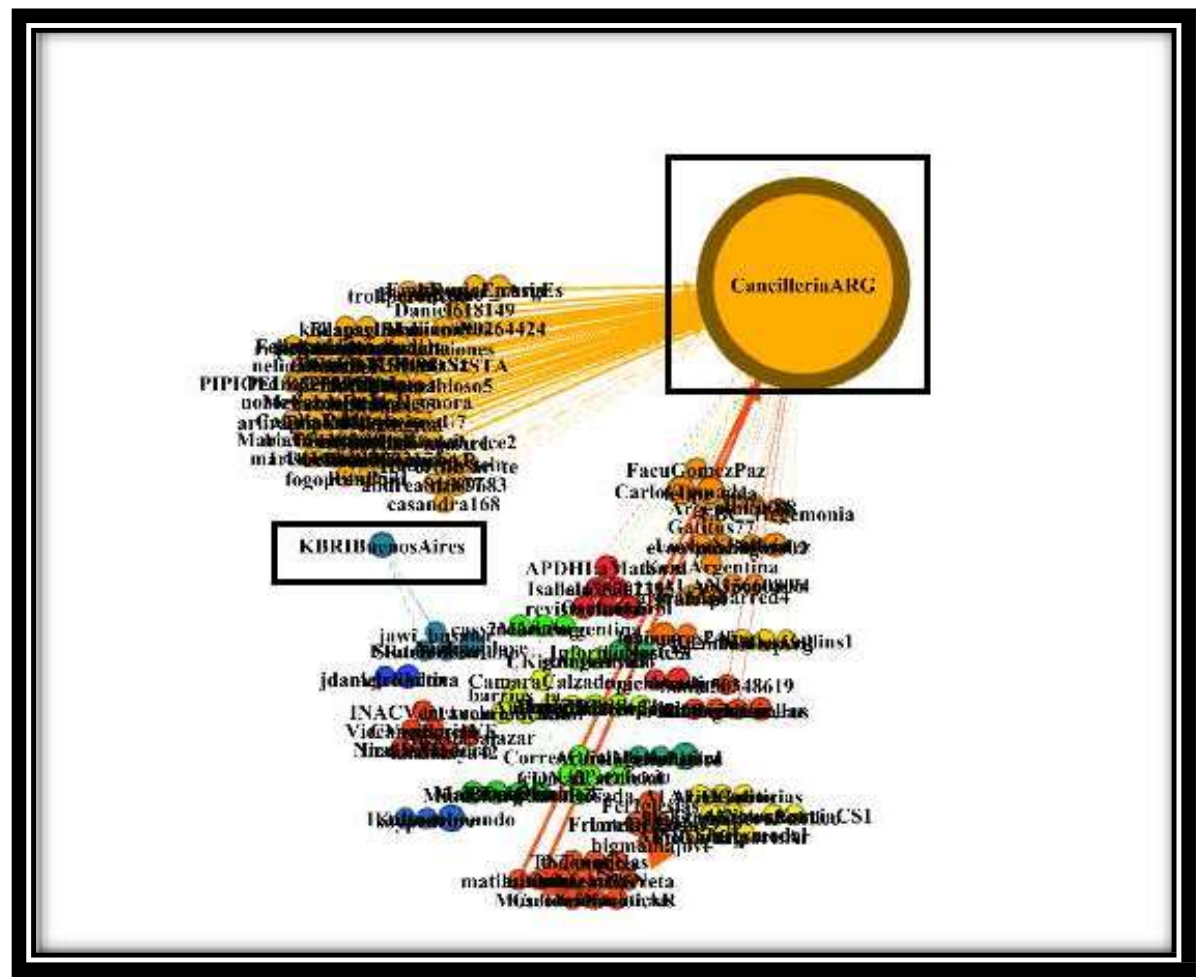

Gambar 2

Gephi Kekuatan Diplomasi Digital antara Indonesia dan Argentina (serta Paraguay dan Uruguay) dengan circle park layout

Kemudian, pilih lagi tab data laboratory, lalu pilih export table. Kemudian buka file tersebut dengan microsoft excel 2016 dan lakukan normalize, kemudian tambahkan kolom country, cluster, level of influence, level of interest, serta digital diplomacy index. 
Penerapan Analisis Jejaring Sosial dalam Mengetahui Kekuatan Diplomasi Digital Indonesia di Kawasan Amerika Selatan

Dimana cluster disini terbagi menjadi government, NGO, mass media dan other.

\begin{tabular}{|c|c|c|c|c|c|c|}
\hline Id & Label & Country = & Cluster & If Influen - & Level of Interes - & Disital Diplomacy index \\
\hline CancilleriaARG & CancilleriaARG & Argentina & Gov & 100 & 100 & 100 \\
\hline CarlosTomada & CarlosTomada & Argentina & Gov & 10,12658228 & 6,260593532 & 8,193587905 \\
\hline felipe_sola & felipe_sola & Argentina & Gov & 10,12658228 & 5,771209108 & 7,948895693 \\
\hline luisitohe & luisitohe & Árgentina & Dther & 13,92405063 & 1,922266746 & 7,92315869 \\
\hline matiasmasca & matiasmasca & Argentina & Dther & 13,92405063 & 1,922266746 & 7,92315869 \\
\hline LBC_Hegemonia & LBC_Hegemonia & Argentina & Mass Media & 11,39240506 & 4,242311423 & 7,817358243 \\
\hline VictorGarciaCS1 & VictorGarciaCS1 & Argentina & Dther & 11,39240506 & 2,103520237 & 6,74796265 \\
\hline ViajeroPublico & ViajeroPublico & Argentina & Dther & 11,39240506 & 1,922266746 & 6,657335905 \\
\hline FacuGomezPaz & FacuGomezPaz & Árgentina & Other & 10,12658228 & 2,615928753 & 6,371255516 \\
\hline armandobarred 4 & armandobarred4 & Argentina & Dther & 8,860759494 & 2,40136381 & 5,631061652 \\
\hline grafespi & grafespi & Argentina & Dther & 8,860759494 & 2,018771983 & 5,439765738 \\
\hline NicasiaSalazar & NicasiaSalazar & Argentina & Other & 8,860759494 & 1,922266746 & 5,39151312 \\
\hline CamaraCalzado & CamaraCalzado & Argentina & Dther & 7,594936709 & 2,575269186 & 5,085102947 \\
\hline trollperoncho & trollperoncho & Argentina & Dther & 6,329113924 & 2,738397327 & 4,533755626 \\
\hline EmbRusiaEnÁrgEs & EmbRusiaEnÁrgEs & Rusia & Gov & 5,063291139 & 3,35759844 & 4,21044479 \\
\hline mae_rusia & mae_rusia & Rusia & Gov & 5,063291139 & 3,35759844 & 4,21044479 \\
\hline 2Marceargentina & 2Marceargentina & Argentina & Dther & 6,329113924 & 1,922266746 & 4,125690335 \\
\hline advocatus 94 & advocatus 94 & Argentina & Dther & 6,329113924 & 1,922266746 & 4,125690335 \\
\hline ALAN35660806 & ALAN35660806 & Argentina & Dther & 6,329113924 & 1,922266746 & 4,125690335 \\
\hline AndreaZinik & AndreaZinik & Argentina & Gov & 6,329113924 & 1,922266746 & 4,125690335 \\
\hline BondiRemo & BondiRemo & Argentina & Other & 6,329113924 & 1,922266746 & 4,125690335 \\
\hline DanielRisafi & DanielRisafi & Argentina & Other & 6,329113924 & 1,922266746 & 4,125690335 \\
\hline ZPerruccio & ZPerruccio & Argentina & Other & 6,329113924 & 1,922266746 & 4,125690335 \\
\hline KBRIBuenosAires & KBRIIBuenosÁires & Indonesia & Gov & 3,797468354 & 4,371148363 & 4,084308359 \\
\hline Xiahpoplove & Xiahpoplove & Argentina & Mass Media & 3,797468354 & 4,371148363 & 4,084308359 \\
\hline Ambitol & Ambitol & Argentina & Mass Media & 2,53164557 & 5,187278944 & 3,859462257 \\
\hline tuvozalmundo & tuvozalmundo & Argentina & Mass Media & 2,53164557 & 5,187278944 & 3,859462257 \\
\hline APDHLaMatanza & APDHLaMatanza & Argentina & Dther & 3,797468354 & 3,555017782 & 3,676243068 \\
\hline claukorol & claukorol & Argentina & Dther & 3,797468354 & 3,555017782 & 3,676243068 \\
\hline revistacitrica & revistacitrica & Argentina & Gov & 3,797468354 & 3,555017782 & 3,676243068 \\
\hline HadBrunstein & HadBrunstein & Argentina & Other & 3,797468354 & 3,342412337 & 3.569940346 \\
\hline
\end{tabular}

Tabel 1

Rekap Excel dari Hasil Export Table Gephi

\begin{tabular}{|c|c|c|c|c|c|c|}
\hline Id & Label & Country = & Cluster & Level of Influene & terest $=$ & Dirital Diplamaxy index \\
\hline nzb 77 & nzb 77 & Argentina & Dther & 3,797468354 & 3,342412337 & 3,569940346 \\
\hline ArgentinoK88 & ArgentinoK88 & Árgentina & Other & 5,063291139 & 1,922266746 & 3,492778943 \\
\hline elFPin86 & elFPin86 & Argentina & Dther & 5,063291139 & 1,922266746 & 3,492778943 \\
\hline Sonia50348619 & Sonia50348619 & Argentina & Dther & 5,063291139 & 1,922266746 & 3,492778943 \\
\hline arielschale & arielschale & Argentina & Drther & 3,797468354 & 3,122458777 & 3,459963566 \\
\hline barrios_ja & barrios_ja & Argentina & Gov & 3,797468354 & 3,122458777 & 3,459963566 \\
\hline UاÁcomunicacion & UlÁcomunicacion & Argentina & NGO & 3,797468354 & 3,122458777 & 3,459963566 \\
\hline alferdez & alferdez & Argentina & Gov & 2,53164557 & 3,881274065 & 3,206459817 \\
\hline Ferlglesias & Ferlglesias & Argentina & NGO & 2,53164557 & 3,555017782 & 3,043331676 \\
\hline FrenteDeTodos & FrenteDeTodos & Argentina & Mass Media & 2,53164557 & 3,555017782 & 3,043331676 \\
\hline gacanteros & gacanteros & Argentina & Gov & 2,53164557 & 3,40658587 & 2,96911572 \\
\hline andrea81609683 & andrea81609683 & Argentina & Dther & 3,797468354 & 1,922266746 & 2,85986755 \\
\hline Bezmiliana & Bezmiliana & Argentina & Dther & 3,797468354 & 1,922266746 & 2,85986755 \\
\hline casandra168 & casandra168 & Argentina & Dther & 3,797468354 & 1,922266746 & 2,85986755 \\
\hline critic_ar_te & critic_ar_te & Argentina & Dther & 3,797468354 & 1,922266746 & 2,85986755 \\
\hline DeltaUnidad & DeltaUnidad & Argentina & Dther & 3,797468354 & 1,922266746 & 2,85986755 \\
\hline Isabel47570219 & Isabel47570219 & Argentina & Dther & 3,797468354 & 1,922266746 & 2,85986755 \\
\hline lauraale1315 & lauraale1315 & Argentina & Dther & 3,797468354 & 1,922266746 & 2,85986755 \\
\hline MatiasCollins1 & MatiasCollins1 & Argentina & Qther & 3,797468354 & 1,922266746 & 2,85986755 \\
\hline Dsofranco & Dsofranco & Argentina & Mass Media & 3,797468354 & 1,922266746 & 2,85986755 \\
\hline MalvinasData & MalvinasData & Argentina & Dther & 2,53164557 & 3,010767437 & 2,771206503 \\
\hline MindefArg & MindefArg & Argentina & Gov & 2,53164557 & 3,010767437 & 2,771206503 \\
\hline laracooltaa & laracooltaa & Argentina & Dther & 2,53164557 & 2,330332037 & 2,430988803 \\
\hline AlMASIntermodal & ÁlMASIntermodal & Argentina & \begin{tabular}{|l|} 
Other \\
\end{tabular} & 2,53164557 & 2,326902917 & 2,429274243 \\
\hline ALAFlatino & ALAFlatino & Argentina & NGO & 2,53164557 & 2,326902917 & 2,429274243 \\
\hline ALALDGok & ALALDGok & Argentina & Mass Media & 2,53164557 & 2,326902917 & 2,429274243 \\
\hline chiletransporte & chiletransporte & Argentina & Other & 2,53164557 & 2,326902917 & 2,429274243 \\
\hline GlobalportsAr & GlobalportsAr & Argentina & Mass Media & 2,53164557 & 2,326902917 & 2,429274243 \\
\hline rieles_arg & rieles_arg & Argentina & Dther & 2,53164557 & 2,326902917 & 2,429274243 \\
\hline rielesnoticias & rielesnoticias & Argentina & Mass Media & 2,53164557 & 2,326902917 & 2,429274243 \\
\hline TradeNewsAr & TradeNewsAr & \begin{tabular}{|l} 
Argentina \\
\end{tabular} & Mass Media & 2,53164557 & 2,326902917 & 2,429274243 \\
\hline AgroActiva & AgroActiva & Argentina & Mass Media & 1,265822785 & 3,555017782 & 2,410420284 \\
\hline InformeNorteSi & InformeNorteSi & Argentina & Mass Media & 1,265822785 & 3,555017782 & 2,410420284 \\
\hline Luciana_I & Iuciana_l & Argentina & Dther & 1,265822785 & 3,555017782 & 2,410420284 \\
\hline
\end{tabular}

\section{Tabel 2}

Rekap Excel dari Hasil Export Table Gephi 


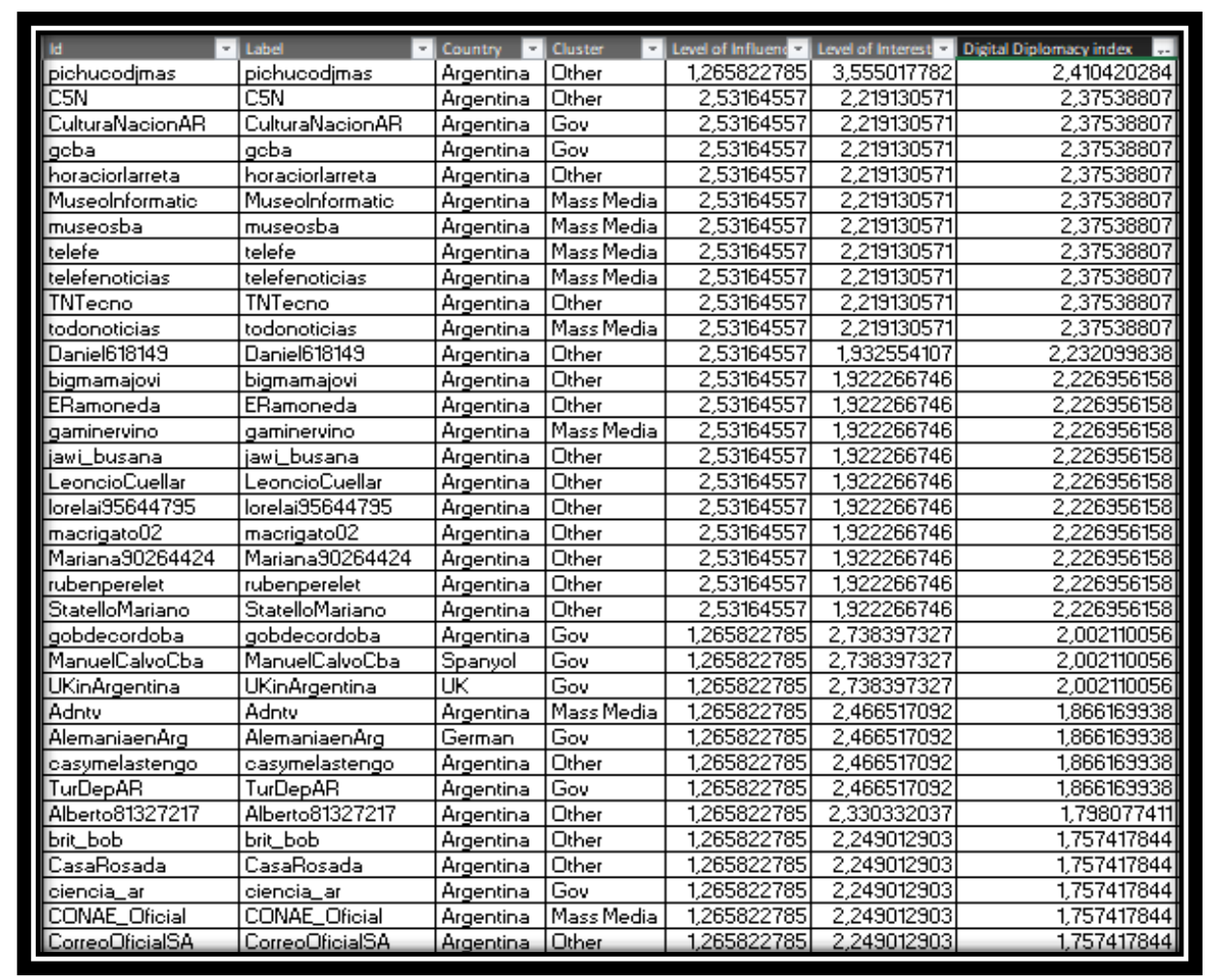

Tabel 3

Rekap Excel dari Hasil Export Table Gephi

\begin{tabular}{|c|c|c|c|c|c|c|}
\hline id & Label & Country $=$ & Cluster & Level of Influend & Level of Interest? & Dixital Diplomacy index \\
\hline evoespueblo & evoespueblo & Argentina & Gov & 1,265822785 & 2,249012903 & 1,757417844 \\
\hline KentArgentina & KentÁrgentina & UK & Gou & 1,265822785 & 2,249012903 & 1,757417844 \\
\hline LuchoXBolivia & LuchoXBolivia & Bolivia & Gov & 1,265822785 & 2,249012903 & 1,757417844 \\
\hline TGrushenko & TGrushenko & Argentina & Other & 1,265822785 & 2,249012903 & 1,757417844 \\
\hline Cancilleria'VE & Cancilleria'VE & Venezuela & Other & 1,265822785 & 2,155446912 & 1,710634849 \\
\hline INACVenezuela & INACVenezuela & Venezuela & Other & 1,265822785 & 2,155446912 & 1,710634849 \\
\hline Inacvizla & Inacuzla & Venezuela & Gov & 1,265822785 & 2,155446912 & 1,710634849 \\
\hline luissalaya42 & luissalaya 42 & Argentina & Other & 1,265822785 & 2,155446912 & 1,710634849 \\
\hline Nicolas/Maduro & NicolasMaduro & Argentina & Gov & 1,265822785 & 2,155446912 & 1,710634849 \\
\hline ViceVlenezuela & ViceVenezuela & Argentina & Mass Media & 1,265822785 & 2,155446912 & 1,710634849 \\
\hline bolettieriok & bolettieriok & Argentina & Gov & 1,265822785 & 2,070698659 & 1,668260722 \\
\hline rafabielsasic & rafabielsasic & Argentina & Other & 1,265822785 & 2,070698659 & 1,668260722 \\
\hline _fechee & _fechee & Argentina & Other & 1,265822785 & 1,922266746 & 1,594044766 \\
\hline AranoMariaLaura & AranoMariaLaura & Argentina & Qther & 1,265822785 & 1,922266746 & 1,594044766 \\
\hline ariirapoport & ariirapoport & Argentina & Dther & 1,265822785 & 1,922266746 & 1,594044766 \\
\hline Beagagliardi & Beagagliardi & Argentina & Other & 1,265822785 & 1,922266746 & 1,594044766 \\
\hline bochinesco69 & bochinesco69 & Argentina & Other & 1,265822785 & 1,922266746 & 1,594044766 \\
\hline CandiaLucas & CandiaLucas & Argentina & Other & 1,265822785 & 1,922266746 & 1,594044766 \\
\hline cazdigital & cazdigital & Argentina & Other & 1,265822785 & 1,922266746 & 1,594044766 \\
\hline CeferinoConurba & CeferinoConurba & Argentina & Other & 1,265822785 & 1,922266746 & 1,594044766 \\
\hline cubrepiletta & cubrepiletta & Argentina & Dther & 1,265822785 & 1,922266746 & 1,594044766 \\
\hline danna_ediciones & danna_ediciones & Argentina & Dther & 1,265822785 & 1,922266746 & 1,594044766 \\
\hline Dardo17758498 & Dardo17758498 & Argentina & Dther & 1,265822785 & 1,922266746 & 1,594044766 \\
\hline en_patricio & en_patricio & Argentina & Dther & 1,265822785 & 1,922266746 & 1,594044766 \\
\hline enebor2 & enebor 2 & Argentina & Dther & 1,265822785 & 1,922266746 & 1,594044766 \\
\hline EsterLinaLanzi & EsterLinaLanzi & Argentina & Dther & 1,265822785 & 1,922266746 & 1,594044766 \\
\hline FeliciottiJose & FeliciottiJose & Árgentina & Dther & 1,265822785 & 1,922266746 & 1,594044766 \\
\hline fogopremium & fogopremium & Argentina & Other & 1,265822785 & 1,922266746 & 1,594044766 \\
\hline Gatitus 77 & Gatitus 77 & Argentina & Other & 1,265822785 & 1,922266746 & 1,594044766 \\
\hline GestionUrbanaSz & GestionUrbanaSz & Argentina & Other & 1,265822785 & 1,922266746 & 1,594044766 \\
\hline GuardiaViejaÁr1 & GuardiaViejaAr1 & Argentina & Other & 1,265822785 & 1,922266746 & 1,594044766 \\
\hline Kaltner & IKaltner & Argentina & Dther & 1,265822785 & 1,922266746 & 1,594044766 \\
\hline idanielvillalon & idanielvillalon & Argentina & Other & 1,265822785 & 1,922266746 & 1,594044766 \\
\hline imtauro55 & imtauro55 & Argentina & Qther & 1,265822785 & 1,922266746 & 1,594044766 \\
\hline jugueterabioso5 & jugueterabioso5 & Argentina & Other & 1,265822785 & 1,922266746 & 1,594044766 \\
\hline
\end{tabular}

\section{Tabel 4}

Rekap Excel dari Hasil Export Table Gephi 
Penerapan Analisis Jejaring Sosial dalam Mengetahui Kekuatan Diplomasi Digital Indonesia di Kawasan Amerika Selatan

\begin{tabular}{|c|c|c|c|c|c|c|}
\hline Id & Label & Country $=$ & Cluster & Level of Influene - & Level of Interes: & Disital Diplomaxy index \\
\hline imtauro55 & jimtauro55 & Argentina & Other & 1,265822785 & 1,922266746 & 1,594044766 \\
\hline jugueterabioso5 & jugueterabioso5 & Argentina & Other & 1,265822785 & 1,922266746 & 1,594044766 \\
\hline kollapss18 & kollapss18 & Argentina & Other & 1,265822785 & 1,922266746 & 1,594044766 \\
\hline lombrizaa & lombrizaa & Argentina & Other & 1,265822785 & 1,922266746 & 1,594044766 \\
\hline LTeresitaSilva & LTeresitaSilva & Argentina & Other & 1,265822785 & 1,922266746 & 1,594044766 \\
\hline magdmonsters & magdmonsters & Argentina & Other & 1,265822785 & 1,922266746 & 1,594044766 \\
\hline MariaEva1956 & MariaEva1956 & Argentina & Other & 1,265822785 & 1,922266746 & 1,594044766 \\
\hline mariannacrudi & mariannacrudi & Argentina & Other & 1,265822785 & 1,922266746 & 1,594044766 \\
\hline marisolsolari1 & marisolsolari1 & Árgentina & Other & 1,265822785 & 1,922266746 & 1,594044766 \\
\hline MelisadeDro1 & MelisadeDro1 & Argentina & Other & 1,265822785 & 1,922266746 & 1,594044766 \\
\hline mlapaz1 & mlapaz1 & Argentina & Other & 1,265822785 & 1,922266746 & 1,594044766 \\
\hline nangaras24fps & nangaras24fps & Argentina & Other & 1,265822785 & 1,922266746 & 1,594044766 \\
\hline nelidahenri & nelidahenri & Argentina & Dther & 1,265822785 & 1,922266746 & 1,594044766 \\
\hline NKCFKPERDNISTA & NKCFKPERDNISTA & Argentina & Other & 1,265822785 & 1,922266746 & 1,594044766 \\
\hline Noelipurita & Noelipurita & Argentina & Dther & 1,265822785 & 1,922266746 & 1,594044766 \\
\hline nortewebsalta & nortewebsalta & Argentina & Dther & 1,265822785 & 1,922266746 & 1,594044766 \\
\hline Patlux1 & Patlux1 & Argentina & Other & 1,265822785 & 1,922266746 & 1,594044766 \\
\hline Pedro32343971 & Pedro32343971 & Argentina & Other & 1,265822785 & 1,922266746 & 1,594044766 \\
\hline pedroarrospi & pedroarrospi & Argentina & Other & 1,265822785 & 1,922266746 & 1,594044766 \\
\hline PieroCarlo & PieroCarlo & Argentina & Other & 1,265822785 & 1,922266746 & 1,594044766 \\
\hline PIPIDELBDSTERD & PIPIDELBDSTERD & Argentina & Other & 1,265822785 & 1,922266746 & 1,594044766 \\
\hline puidal31 & puidal31 & Argentina & Other & 1,265822785 & 1,922266746 & 1,594044766 \\
\hline RemodelemosAR & RemodelemosAR & Argentina & Other & 1,265822785 & 1,922266746 & 1,594044766 \\
\hline RitaP571 & RitaP571 & Argentina & Other & 1,265822785 & 1,922266746 & 1,594044766 \\
\hline RogelioPeloso & RogelioPeloso & Argentina & Mass Media & 1,265822785 & 1,922266746 & 1,594044766 \\
\hline rogerlorton & rogerlorton & Argentina & Dther & 1,265822785 & 1,922266746 & 1,594044766 \\
\hline rrbbijaa & rrbbijaa & Argentina & Other & 1,265822785 & 1,922266746 & 1,594044766 \\
\hline soypedrozr & soypedrozr & Argentina & Other & 1,265822785 & 1,922266746 & 1,594044766 \\
\hline Susanaป7 & Susanaป7 & Argentina & Qther & 1,265822785 & 1,922266746 & 1,594044766 \\
\hline TioJose33 & TioJose 33 & Argentina & Other & 1,265822785 & 1,922266746 & 1,594044766 \\
\hline Triplededos & Triplededos & Argentina & Other & 1,265822785 & 1,922266746 & 1,594044766 \\
\hline veleaeleonora & veleaeleonora & Argentina & Other & 1,265822785 & 1,922266746 & 1,594044766 \\
\hline ZHoracio & ZHoracio & Argentina & Other & 1,265822785 & 1,922266746 & 1,594044766 \\
\hline ZurdoEmpobrece2 & ZurdoEmpobrece2 & Argentina & Other & 1,265822785 & 1,922266746 & 1,594044766 \\
\hline
\end{tabular}

Tabel 5

Rekap Excel dari Hasil Export Table Gephi

Kemudian penulis juga mencoba Fruchterman Reingold layout, dengan cara pilih pada tab layout.

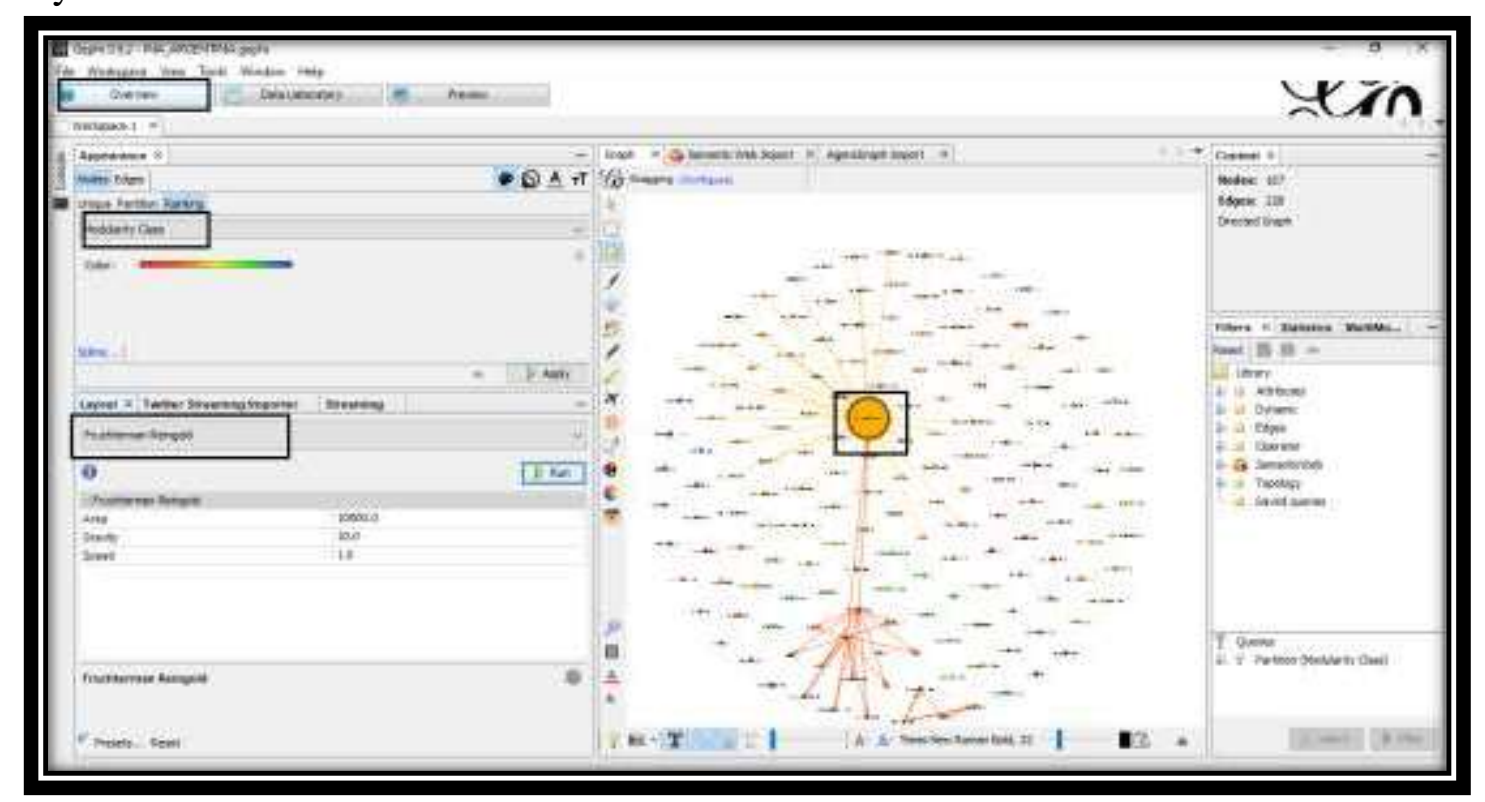

Gambar 3

Gephi Kekuatan Diplomasi Digital antara Indonesia dan Argentina (serta Paraguay dan Uruguay) dengan Fruchterman Reingold layout 


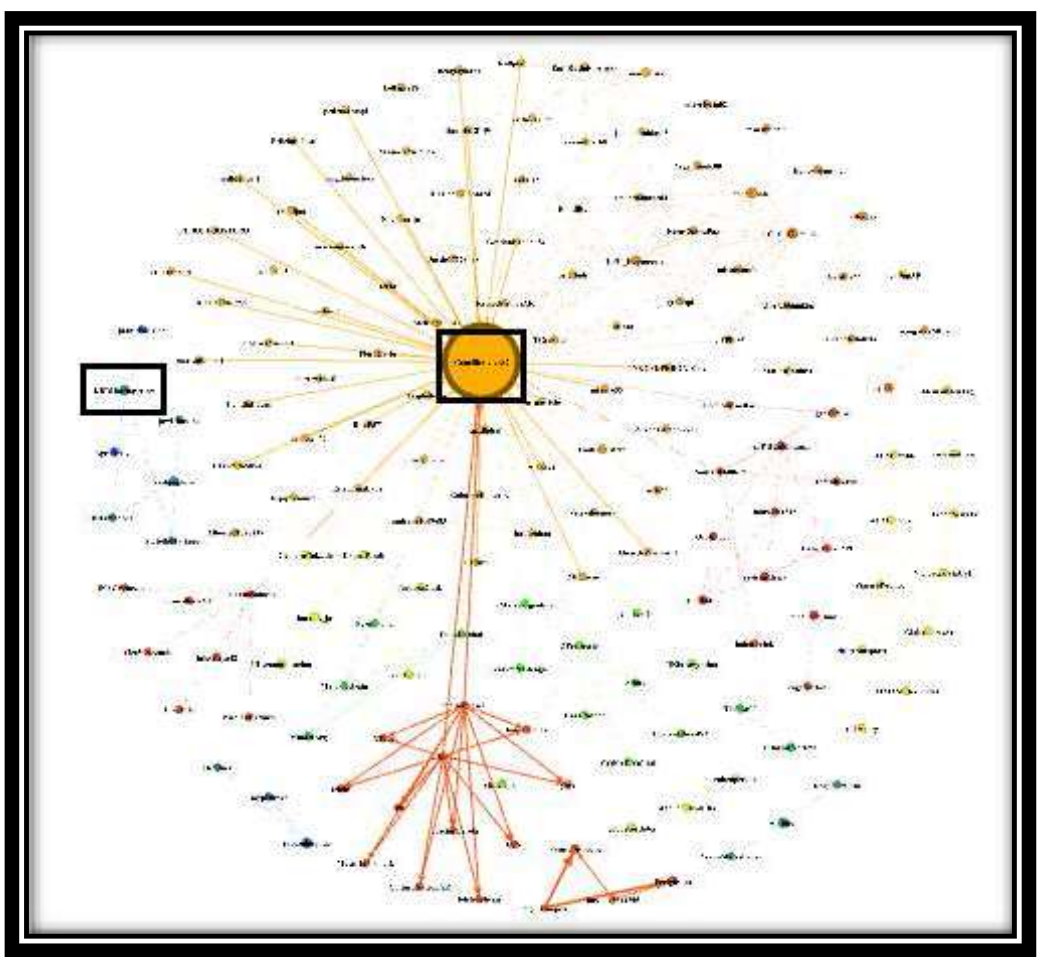

Gambar 4

Gephi Kekuatan Diplomasi Digital antara Indonesia dan Argentina (serta Paraguay dan Uruguay) dengan Fruchterman Reingold layout

\section{c. Hasil Analisa}

\begin{tabular}{|c|c|c|c|c|c|c|}
\hline id & Label & Country & Cluster & Level of Influen & Level of Interes = & Digital Diplomacy index \\
\hline EancilleriaARG & TancilleriaARIG & Argentina & Gov & 700 & 700 & 700 \\
\hline Carloslomada & Larloslomada & Argentina & Gov & 10,12658228 & 6,260595553 & 8,1935874005 \\
\hline felipe_sola & felipe_sola & Argentina & Gov & 10,12658228 & 5,771209108 & 7,948895693 \\
\hline luisitohe & luisitohe & Argentina & Other & 13,92405063 & 1,922266746 & 7,92315869 \\
\hline matiasmasca & matiasmasca & Argentina & Other & 13,92405063 & 1,922266746 & 7,92315869 \\
\hline LBC_Hegemonia & LBC_Hegemonia & Argentina & Mass Media & 11,39240506 & 4,242311423 & 7,817358243 \\
\hline VictorGarciaCS1 & VictorGarciaCS1 & Argentina & Other & 11,39240506 & 2,103520237 & 6,74796265 \\
\hline ViajeroPublico & ViajeroPublico & Argentina & Dther & 11,39240506 & 1,922266746 & 6,657335905 \\
\hline FacuGomezPaz & FacuGomezPaz & Argentina & Other & 10,12658228 & 2,615928753 & 6,371255516 \\
\hline armandobarred4 & armandobarred4 & Argentina & Dther & 8,860759494 & 2,40136381 & 5,631061652 \\
\hline grafespi & grafespi & Argentina & Dther & 8,860759494 & 2,018771983 & 5,439765738 \\
\hline NicasiaSalazar & NicasiaSalazar & Argentina & Dther & 8,860759494 & 1,922266746 & 5,39151312 \\
\hline CamaraCalzado & CamaraCalzado & Argentina & Other & 7,594936709 & 2,575269186 & 5,085102947 \\
\hline trollperoncho & trollperoncho & Argentina & Other & 6,329113924 & 2,738397327 & 4,533755626 \\
\hline EmbRusiaEnÁrgEs & EmbRusiaEnÁrgEs & Rusia & Gov & 5,063291139 & 3,35759844 & 4,21044479 \\
\hline mae_rusia & mae_rusia & Rusia & Gov & 5,063291139 & 3,35759844 & 4,21044479 \\
\hline 2Marceargentina & 2Marceargentina & Argentina & Other & 6,329113924 & 1,922266746 & 4,125690335 \\
\hline advocatus94 & advocatus 94 & Argentina & Other & 6,329113924 & 1,922266746 & 4,125690335 \\
\hline ALAN35660806 & ALAN35660806 & Argentina & Other & 6,329113924 & 1,922266746 & 4,125690335 \\
\hline AndreaZinik & AndreaZinik & Argentina & Gov & 6,329113924 & 1,922266746 & 4,125690335 \\
\hline BondiRemo & BondiRemo & Argentina & Other & 6,329113924 & 1,922266746 & 4,125690335 \\
\hline DanielRisafi & DanielRisafi & Argentina & Other & 6,329113924 & 1,922266746 & 4,125690335 \\
\hline ZPerruccio & ZPerruccio & Argentina & Other & 6,329113924 & 1,922266746 & 4,125690335 \\
\hline MEFIDUEnoshires & KEARIDUEnos Aाres & jundonessa & Gov & 3,197466554 & 4,571146565 & 4,064506559 \\
\hline Xiahpoplove & Xiahpoplove & Argentina & flMassmedia & 3,797468354 & 4,371148363 & 4,084508359 \\
\hline Ambitol & Ambitol & Argentina & Mass Media & 2,53164557 & 5,187278944 & 3,859462257 \\
\hline tuvozalmundo & tuvozalmundo & Argentina & Mass Media & 2,53164557 & 5,187278944 & 3,859462257 \\
\hline APDHLaMatanza & APDHLaMatanza & Argentina & Other & 3,797468354 & 3,555017782 & 3,676243068 \\
\hline claukorol & claukorol & Argentina & Other & 3,797468354 & 3,555017782 & 3,676243068 \\
\hline revistacitrica & revistacitrica & Argentina & Gov & 3,797468354 & 3,555017782 & 3,676243068 \\
\hline HadBrunstein & HadBrunstein & Argentina & Other & 3.797468354 & 3,342412337 & 3,569940346 \\
\hline
\end{tabular}

Tabel 6

Rekap Excel dari Hasil Export Table Gephi

Melalui tabel 6 dapat dilihat bahwa, pengaruh Cancilleria ARG (Kedutaan Besar Argentina, Paraguay dan Uruguay di Indonesia) jauh lebih besar dibandingkan dengan 
KBRIBuenosAires (Kedutaan Besar Indonesia di Argentina dan Paraguay). Hal ini juga dapat dilihat pada, besarnya level of influence, level of interest serta digital diplomacy index. Dibuktikan juga dengan nodes dan edges seperti berikut.

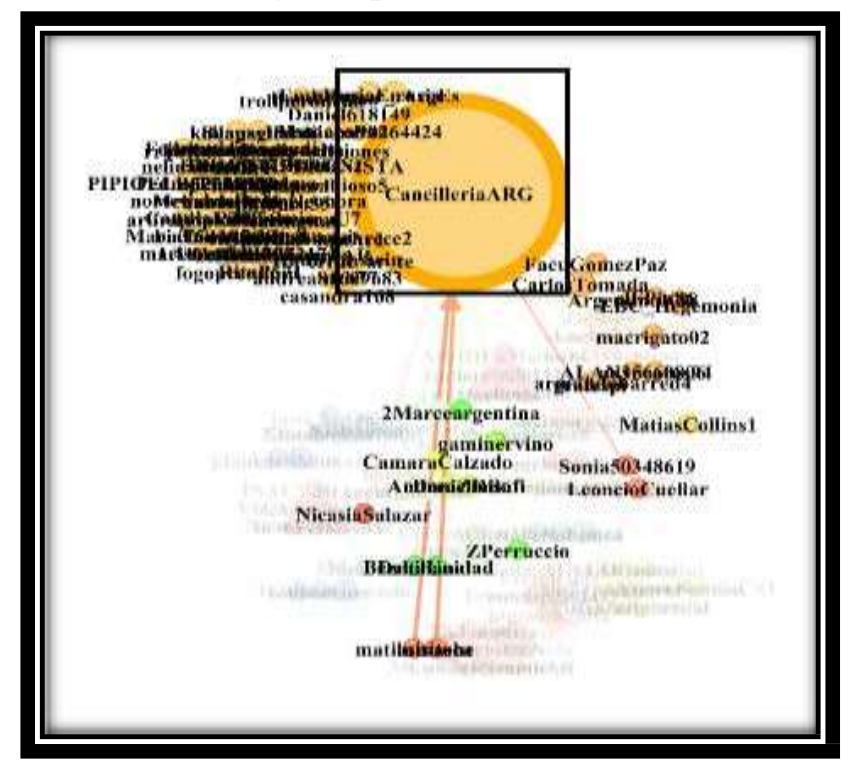

Gambar 5

Gephi Kekuatan Diplomasi Digital antara Indonesia dan Argentina (serta Paraguay) dengan circle park layout

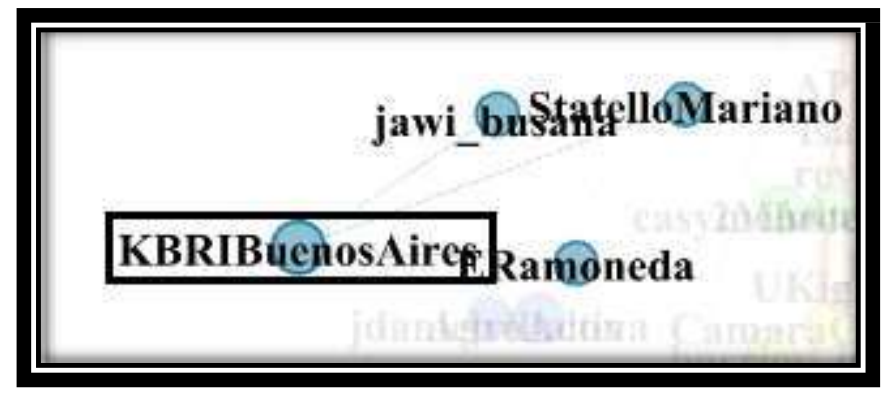

\section{Gambar 6}

Gephi Kekuatan Diplomasi Digital antara Indonesia dan Argentina (serta Paraguay) dengan circle park layout

Dan jika dilakukan filter berdasarkan partition, maka hasil untuk CancilleriaARG

(Kedutaan Besar Argentina di Indonesia) adalah sebagai berikut.

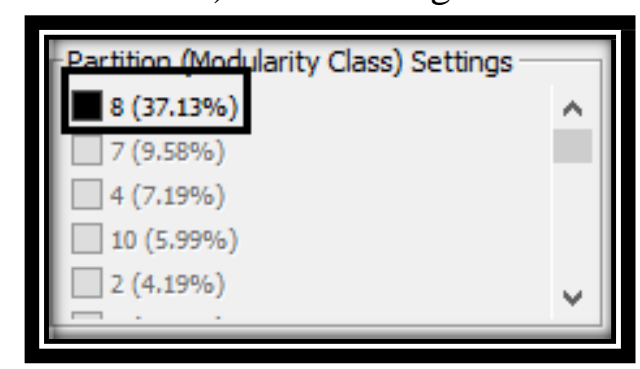

Gambar 7

Gephi Kekuatan Diplomasi Digital antara Indonesia dan Argentina (serta Paraguay dan Uruguay) dengan filter modularity class (node) 


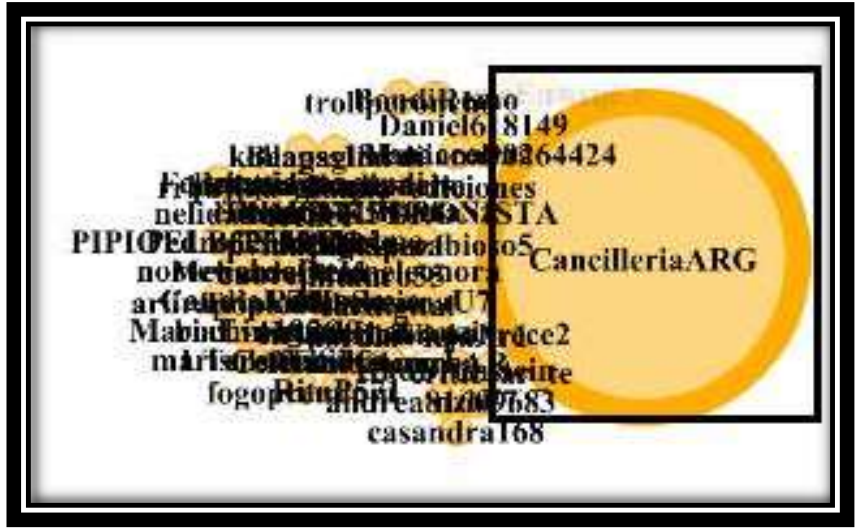

Gambar 8

Gephi Kekuatan Diplomasi Digital antara Indonesia dan Argentina (serta Paraguay dan Uruguay) dengan filter modularity class (node)

Hal ini tentunya berbanding cukup signifikan dengan keberadaan KBRIBuenosAires (Kedutaan Besar Argentina, Paraguay dan Uruguay di Indonesia) jauh lebih besar dibandingkan dengan KBRIBuenosAires (Kedutaan Besar Indonesia di Argentina) pada studi kasus ini, dimana kekuatan diplomasi digitalnya tidak terlalu kuat.

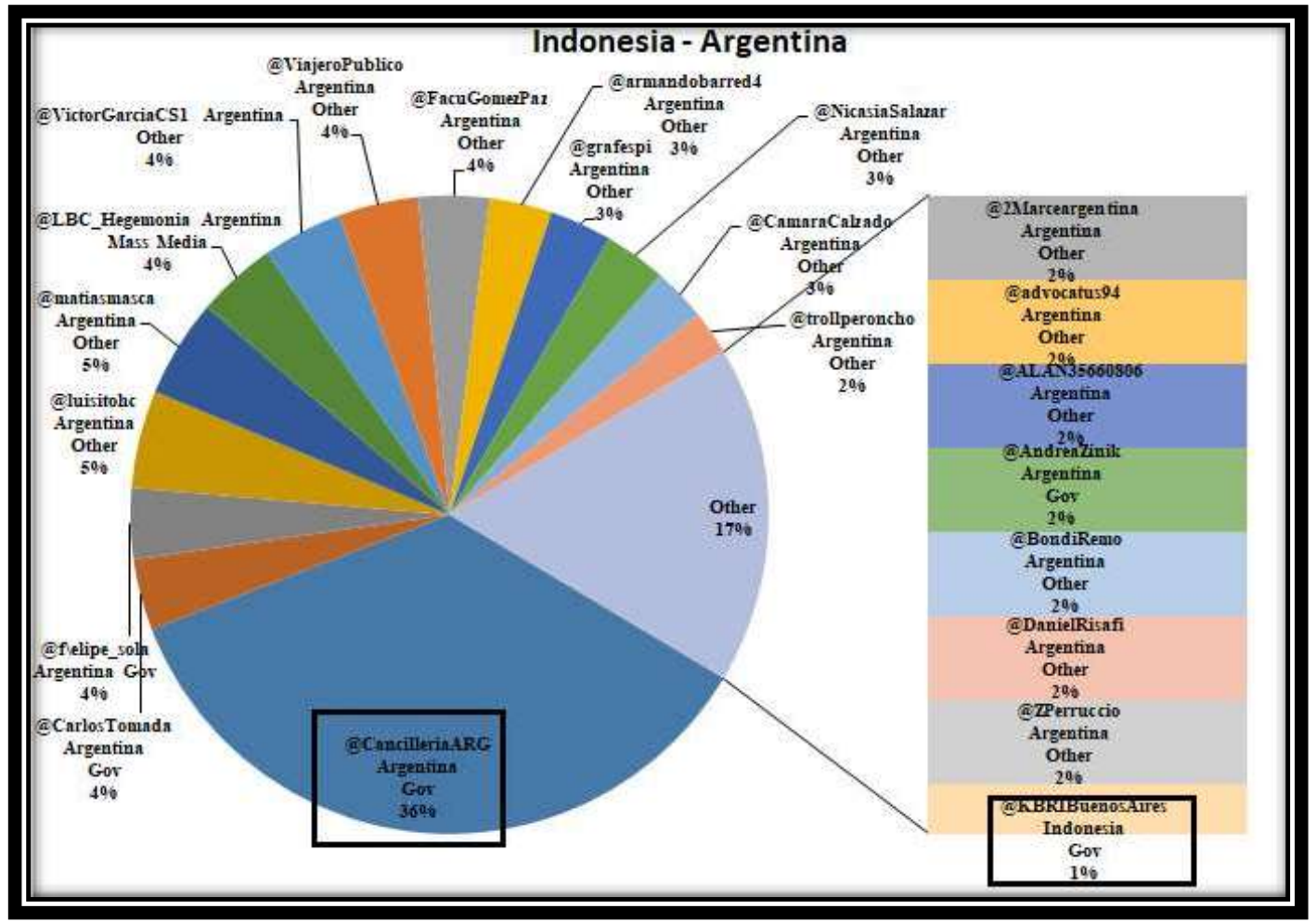

Gambar 9

Data hasil analisa kekuatan diplomasi digital Indonesia dengan Amerika Selatan

Dan jika dilihat dari country, Argentina lebih unggul dalam hal studi kasus diplomasi digital ini. Serta jika dilihat dari cluster, peran pemerintah condong lebih besar pengaruhnya, meskipun aktor yang terlibat atau nodes lebih banyak peran other atau masyarakat digital. Kemudian, country atau parties yang terlibat yakni Argentina, Bolivia, Jerman, Indonesia, Rusia, Spanyol, UK dan Venezuela. 


\section{d. Bolivia dan Peru}

1. Akun Twitter Resmi

Tidak ada data ketika grabbing data.

$\rightarrow$ @ kbrilima (Akun twitter resmi Kedutaan Besar Indonesia di Bolivia dan Peru).

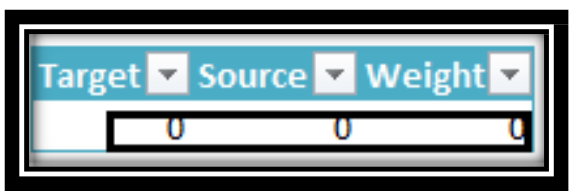

Tabel 7

\section{Brazil}

Akun twitter tidak aktif, grabbing data kosong

\section{Akun Twitter Resmi}

$\rightarrow$ @KBRI_Brasilia (Akun twitter resmi Kedutaan Besar Indonesia di Brazil) dan @BrasembJacarta (Akun twitter resmi Kedutaan Besar Brazil di Indonesia). Pada saat dilakukan grabbing data, ditemukan bahwa @BrasembJacarta (Akun twitter resmi Kedutaan Besar Brazil di Indonesia) tidak ada datanya.

\section{Analisa Data}

Untuk dapat melakukan analisa ini, penulis melakukan grabbing data melalui microsoft excel 2016, lalu setelah data didapat dari kedua akun twitter resmi tersebut, data selanjutnya di merge atau combine masih dalam microsoft excel 2016, kemudian hapus kolom selain target, source dan weight, pastikan jika ada baris dari kolom weight yang bernilai 0 , ubah terlebih dahulu menjadi 1 . Kemudian save as dengan format xls. Kemudian buka Gephi 0.9.2, pertama-tama, jalankan plugins yang ada pada tab overview kemudian masuk ke tab data laboratory, klik import spreadsheet lalu pilih file excel yang sudah kita dapat dari hasil grabbing data yang dilakukan, lalu jika berhasil, copy data to other column dan pilih ID, kemudian Label. Setelah itu, pindah lagi ke tab overview. Pada bagian appearance untuk color, pilih ranking berdasarkan degree serta untuk size, pilih ranking berdasarkan PageRank. Kemudian apply. Selanjutnya, pada kolom layout, pilih circle park layout. Juga masukan credentials pada bagian tab twitter streaming importer.

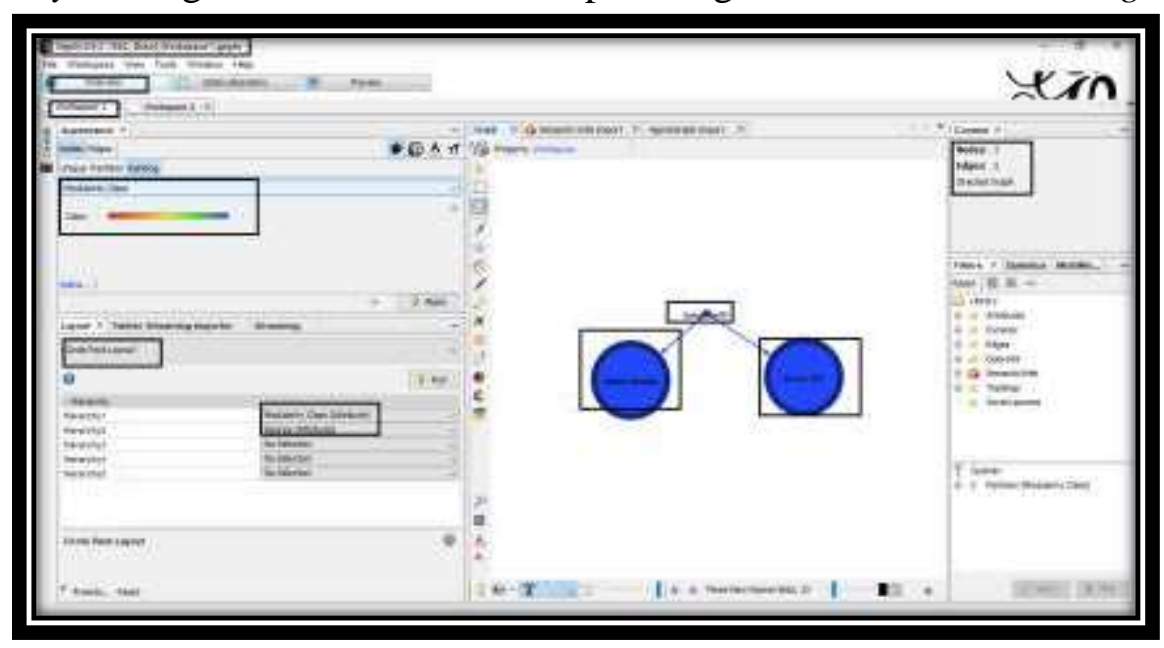

Gambar 10

Gephi Kekuatan Diplomasi Digital antara Indonesia dan Brazil dengan circle park layout 


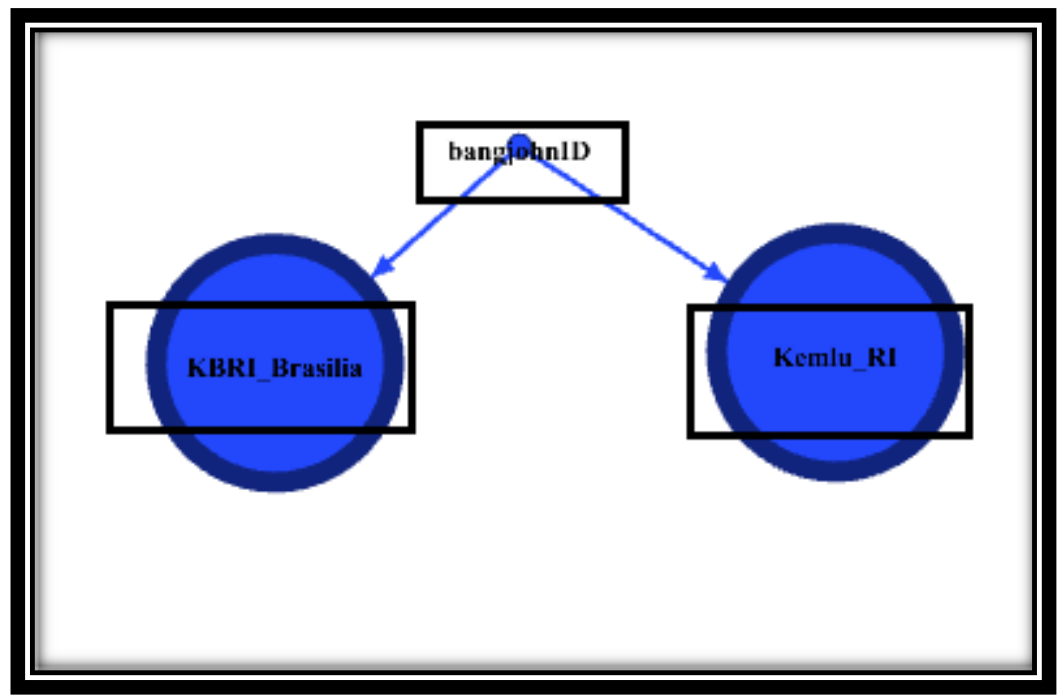

Gambar 11

Gephi Kekuatan Diplomasi Digital antara Indonesia dan Brazil dengan circle park layout

Kemudian, pilih lagi tab data laboratory, lalu pilih export table. Kemudian buka file tersebut dengan microsoft excel 2016 dan lakukan normalize, kemudian tambahkan kolom country, cluster, level of influence, level of interest, serta digital diplomacy index. Dimana cluster disini terbagi menjadi government, NGO, mass media dan other.

\begin{tabular}{|c|c|c|c|c|c|c|}
\hline$\checkmark$ & Label & Country - & Cluste = & Lerel of Influence $*$ & Level of Interest - & Digital Diplomacy Indes * \\
\hline bangjohnID & bangjohnID & Indonesia & Other & 100 & 70,12644619 & 85,06322309 \\
\hline KBRI_Brasilia & KBRI_Brasilia & Indonesia & Gov & 50 & 100 & 75 \\
\hline Kemlu RI & Kemlu RI & Indonesia & Gov & 50 & 100 & 75 \\
\hline
\end{tabular}

Tabel 8

Rekap Excel dari Hasil Export Table Gephi

3. Hasil Analisa

\begin{tabular}{|c|c|c|c|c|c|c|}
\hline Id & Label & $\nabla \longdiv { C o u n t r } \nabla$ & Cluste & Level of Influence $>$ & Level of Interest $\mathbf{v}$ & Digital Diplomacy Indes \\
\hline bangiohnID & |bangiohnID & |Indonesia| & |Other & $100 \mid$ & $70,12644619 \mid$ & 85,06322309 \\
\hline KBRI Brasili & a $\mathrm{KBRI}$ Brasil & lia Indonesia & Gov & 50 & 100 & 75 \\
\hline Kemlu_RI & Kemlu_RI & Indonesia & Gov & 50 & 100 & 75 \\
\hline
\end{tabular}

Tabel 9

Rekap Excel dari Hasil Export Table Gephi

Melalui tabel 8 dapat dilihat bahwa, pengaruh BrasembJacarta (Akun twitter resmi Kedutaan Besar Brazil di Indonesia) sama besarnya dengan KBRI_Brasilia (Akun twitter resmi Kedutaan Besar Indonesia di Brazil). Hal ini juga dapat dilihat pada, besarnya level of influence, level of interest serta digital diplomacy index. Dibuktikan juga dengan nodes dan edges seperti berikut. 


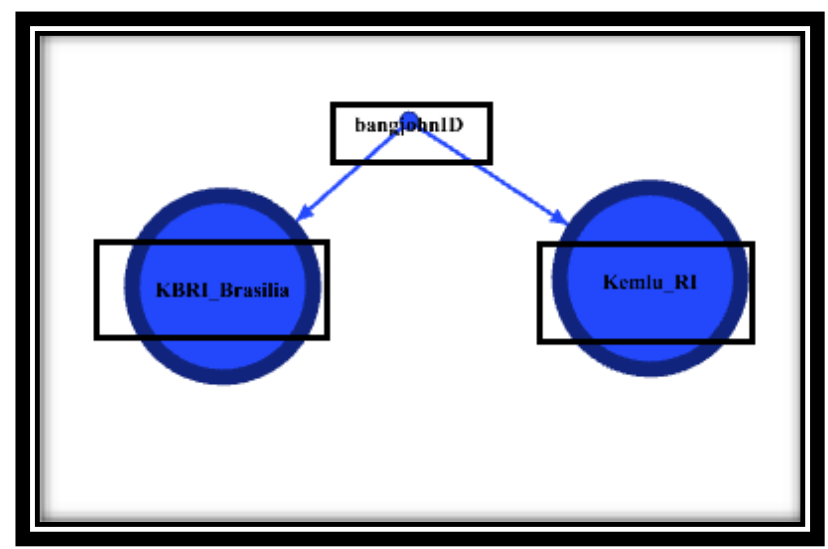

Gambar 12

Gephi Kekuatan Diplomasi Digital antara Indonesia dan Argentina dengan circle park layout

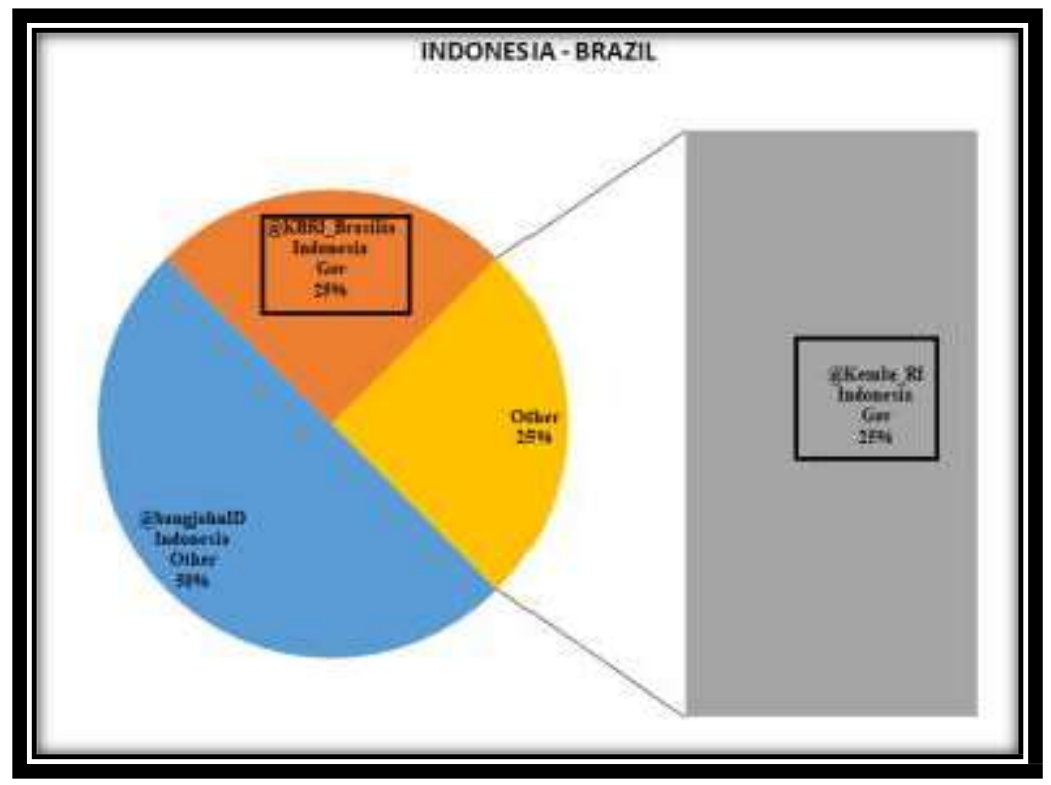

Gambar 13

Data hasil analisa kekuatan diplomasi digital Indonesia dengan Amerika Selatan

Dapat disimpulkan bahwa kekuatan diplomasi digital antara Indonesia dan Brazil, Indonesia jauh lebih unggul terbukti dengan adanya peran other atau masyarakat digital berkewarganegaraan Indoenesia yang menempati posisi teratas dengan akun twitter bangjohnID serta tidak aktifnya BrasembJacarta (Akun twitter resmi Kedutaan Besar Brazil di Indonesia) juga menjadi acuan penting dalam hal ini.

\section{Chile}

1. Akun Twitter Resmi

Tidak ada data ketika grabbing data.

$\rightarrow$ @kbrisantiago (Akun twitter resmi Kedutaan Besar Indonesia di Chile).

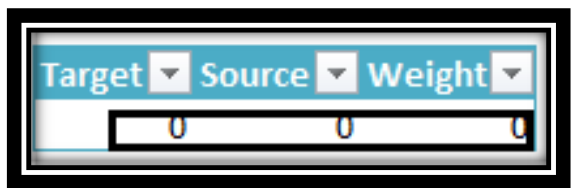

Tabel 10

Akun twitter tidak aktif, grabbing data kosong 


\section{Kolombia}

1. Akun Twitter Resmi

$\rightarrow$ @IndonesiainCOL (Akun twitter resmi Kedutaan Besar Indonesia di Kolombia)dan @CancilleriaCol (Akun twitter resmi Kedutaan Besar Kolombia di Indonesia). Pada saat dilakukan grabbing data, ditemukan bahwa @IndonesiainCOL (Akun twitter resmi Kedutaan Besar Indonesia di Kolombia) tidak ada datanya.

\section{Analisa Data}

Untuk dapat melakukan analisa ini, penulis melakukan grabbing data melalui microsoft excel 2016, lalu setelah data didapat dari kedua akun twitter resmi tersebut, data selanjutnya di merge atau combine masih dalam microsoft excel 2016, kemudian hapus kolom selain target, source dan weight, pastikan jika ada baris dari kolom weight yang bernilai 0 , ubah terlebih dahulu menjadi 1 . Kemudian save as dengan format xls. Kemudian buka Gephi 0.9.2, pertama-tama, jalankan plugins yang ada pada tab overview kemudian masuk ke tab data laboratory, klik import spreadsheet lalu pilih file excel yang sudah kita dapat dari hasil grabbing data yang dilakukan, lalu jika berhasil, copy data to other column dan pilih ID, kemudian Label. Setelah itu, pindah lagi ke tab overview. Pada bagian appearance untuk color, pilih ranking berdasarkan degree serta untuk size, pilih ranking berdasarkan PageRank. Kemudian apply. Selanjutnya, pada kolom layout, pilih circle park layout. Juga masukan credentials pada bagian tab twitter streaming importer.

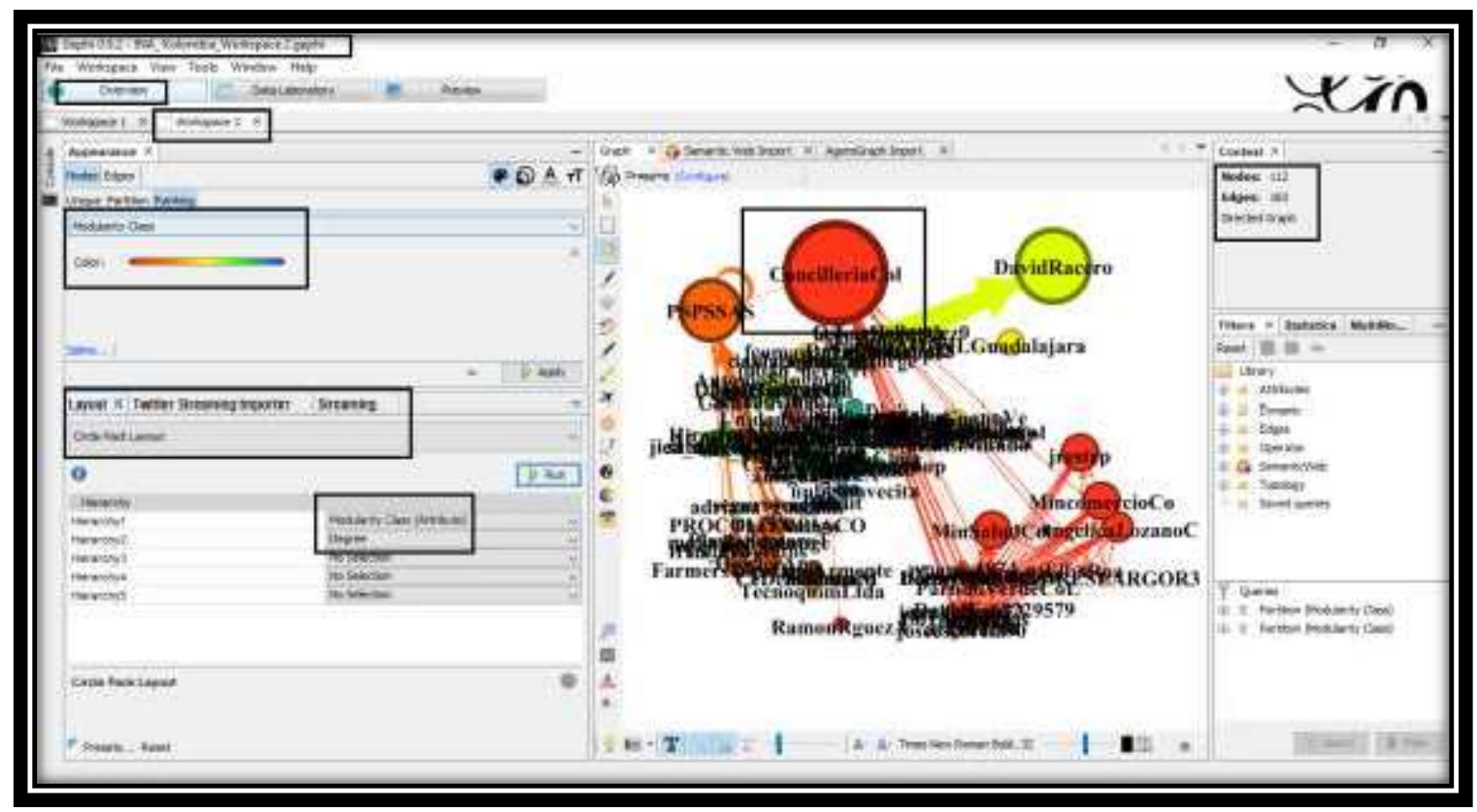

Gambar 14

Gephi Kekuatan Diplomasi Digital antara Indonesia dan Kolombia 


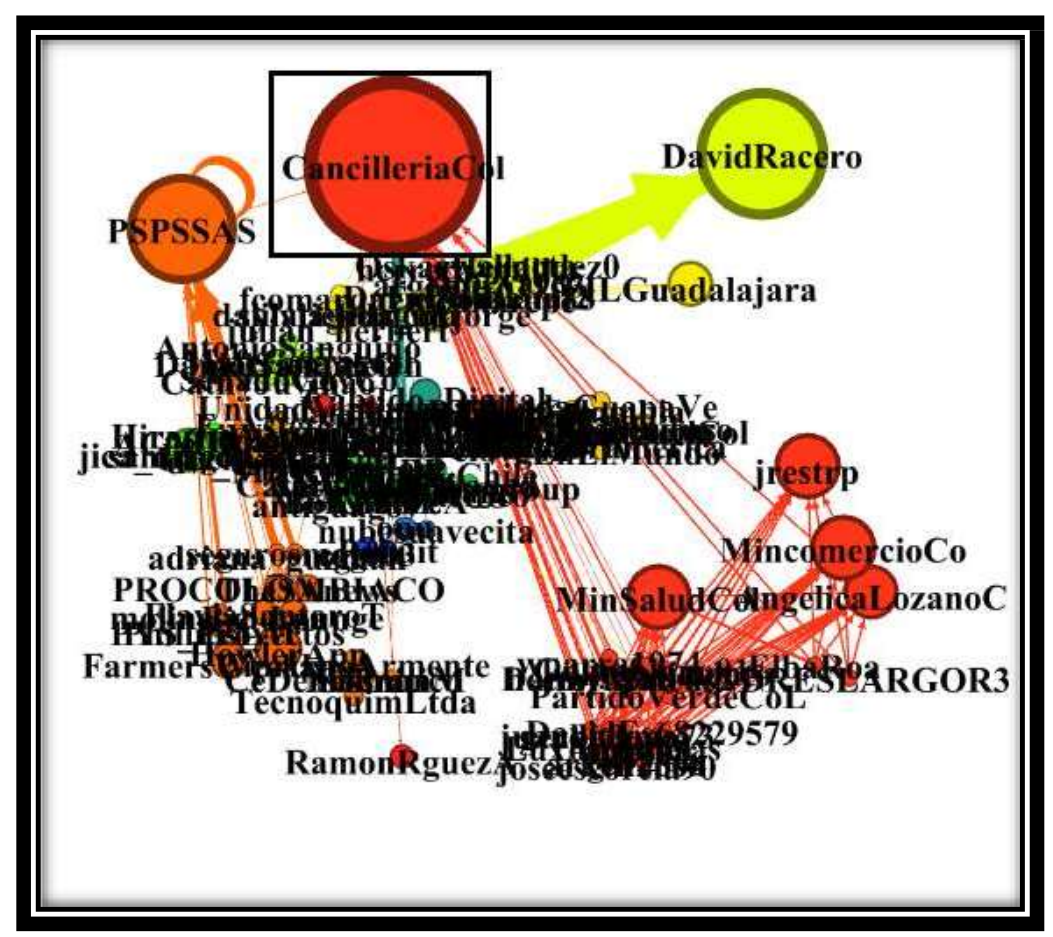

Gambar 15

Gephi Kekuatan Diplomasi Digital antara Indonesia dan Kolombia

Kemudian, pilih lagi tab data laboratory, lalu pilih export table. Kemudian buka file tersebut dengan microsoft excel 2016 dan lakukan normalize, kemudian tambahkan kolom country, cluster, level of influence, level of interest, serta digital diplomacy index. Dimana cluster disini terbagi menjadi government, NGO, mass media dan other.

\begin{tabular}{|c|c|c|c|c|c|c|}
\hline- & Label & Country & - Cluster & - Level of Influence - & Level of Interest - & Digital Diplomacy Index . \\
\hline CancilleriaCol & CancilleriaCol & Colombia & Gov & 100 & 100 & 100 \\
\hline PSPSSAS & PSPSSAS & Colombia & Other & 51,72413793 & 60,78153913 & 56,25283853 \\
\hline DavidRacero & DavidRacero & Colombia & Gov & 27,5862069 & 72,85605436 & 50,22113063 \\
\hline AngelicaLozanoC & AngelicaLozanoC & Colombia & NGO & 58,62068966 & 30,17618063 & 44,39843514 \\
\hline jrestrp & jrestrp & Colombia & Gov & 48,27586207 & 36,59052388 & 42,43319297 \\
\hline MincomercioCo & MincomercioCo & Colombia & Gov & 48,27586207 & 36,59052388 & 42,43319297 \\
\hline MinSaludCol & MinSaludCol & Colombia & Gov & 48,27586207 & 36,59052388 & 42,43319297 \\
\hline cjportillaj & cjportillaj & Colombia & Other & 34,48275862 & 9,342393755 & 21,91257619 \\
\hline FILGuadalajara & FILGuadalajara & Colombia & Mass Media & 13,79310345 & 25,22042016 & 19,5067618 \\
\hline francorjorge & francorjorge & Colombia & Other & 13,79310345 & 25,22042016 & 19,5067618 \\
\hline adriana_guzman & adriana_guzman & Colombia & Gov & 27,5862069 & 9,342393755 & 18,46430033 \\
\hline AnthraxReloaded & AnthraxReloaded & Colombia & Other & 27,5862069 & 9,342393755 & 18,46430033 \\
\hline segurosmagna & segurosmagna & Colombia & Mass Media & 27,5862069 & 9,342393755 & 18,46430033 \\
\hline HowlerApp & HowlerApp & Colombia & Other & 10,34482759 & 26,14564058 & 18,24523408 \\
\hline FarmersWeeklySA & FarmersWeeklySA & Colombia & Mass Media & 13,79310345 & 20,97995615 & 17,3865298 \\
\hline patriotaalcien & patriotaalcien & Colombia & Other & 24,13793103 & 9,342393755 & 16,74016239 \\
\hline VVEnEIMundo & VVEnEIMundo & Colombia & Other & 24,13793103 & 9,342393755 & 16,74016239 \\
\hline jica_direct_en & jica_direct_en & Japan & Mass Media & 6,896551724 & 24,6264131 & 15,76148241 \\
\hline PartidoVerdeCoL & PartidoVerdeCoL & Colombia & Mass Media & 20,68965517 & 10,47598314 & 15,58281916 \\
\hline Cabildo_Digital & Cabildo_Digital & Colombia & Other & 10,34482759 & 17,28062946 & 13,81272852 \\
\hline IvanDuque & IvanDuque & Colombia & Gov & 10,34482759 & 17,28062946 & 13,81272852 \\
\hline ANDRESLARGOR3 & ANDRESLARGOR3 & Colombia & Other & 17,24137931 & 9,342393755 & 13,29188653 \\
\hline arken 2504 & arken 2504 & Colombia & Other & 17,24137931 & 9,342393755 & 13,29188653 \\
\hline DavidEs68229579 & DavidEs68229579 & Colombia & Other & 17,24137931 & 9,342393755 & 13,29188653 \\
\hline dpa_25 & dpa_25 & Colombia & Other & 17,24137931 & 9,342393755 & 13,29188653 \\
\hline ElbaRoa & ElbaRoa & Colombia & Other & 17,24137931 & 9,342393755 & 13,29188653 \\
\hline
\end{tabular}

Tabel 11

Rekap Excel dari Hasil Export Table Gephi 


\begin{tabular}{|c|c|c|c|c|c|c|}
\hline Id & Label & Country & - Cluster & - Level of Influend - & Level of Intere: - & Digital Diplomacy Ind,$\downarrow$ \\
\hline garcosc & garcosc & Colombia & Other & 17,24137931 & 9,342393755 & 13,29188653 \\
\hline gerdicam & gerdicam & Colombia & Mass Media & 17,24137931 & 9,342393755 & 13,29188653 \\
\hline Globalines & Globalines & Colombia & Other & 17,24137931 & 9,342393755 & 13,29188653 \\
\hline joseescorcia90 & joseescorcia90 & Colombia & Other & 17,24137931 & 9,342393755 & 13,29188653 \\
\hline juanbedoya73 & juanbedoya73 & Colombia & Mass Media & 17,24137931 & 9,342393755 & 13,29188653 \\
\hline LuxAndLan & LuxAndLan & Colombia & Other & 17,24137931 & 9,342393755 & 13,29188653 \\
\hline rocovale & rocovale & Colombia & Other & 17,24137931 & 9,342393755 & 13,29188653 \\
\hline SalomnM & SalomnM & Colombia & Mass Media & 17,24137931 & 9,342393755 & 13,29188653 \\
\hline schalelas & schalelas & Colombia & Other & 17,24137931 & 9,342393755 & 13,29188653 \\
\hline PROCOLOMBIACO & PROCOLOMBIACO & Colombia & Gov & 10,34482759 & 15,59035283 & 12,96759021 \\
\hline Biz_Lounge & Biz_Lounge & Colombia & Mass Media & 10,34482759 & 15,2731344 & 12,80898099 \\
\hline FlaviaSantoroT & FlaviaSantoroT & Colombia & Gov & 10,34482759 & 15,04921551 & 12,69702155 \\
\hline TheSAnews & TheSAnews & South African & Mass Media & 10,34482759 & 15,04921551 & 12,69702155 \\
\hline MigracionCol & MigracionCol & Colombia & Mass Media & 6,896551724 & 14,92792611 & 10,91223892 \\
\hline NicolasMaduro & NicolasMaduro & Venezuela & Gov & 6,896551724 & 14,92792611 & 10,91223892 \\
\hline MadaGuapaVe & MadaGuapaVe & Colombia & Other & 10,34482759 & 10,47598314 & 10,41040537 \\
\hline Guambiano01 & Guambiano01 & Colombia & Other & 6,896551724 & 13,31073411 & 10,10364292 \\
\hline santiagopardos & santiagopardos & Japan & Gov & 6,896551724 & 13,31073411 & 10,10364292 \\
\hline camilo_bln & camilo_bln & Colombia & Other & 10,34482759 & 9,342393755 & 9,843610671 \\
\hline libelula_group & libelula_group & Colombia & Other & 10,34482759 & 9,342393755 & 9,843610671 \\
\hline luisenesimo & luisenesimo & Colombia & Other & 10,34482759 & 9,342393755 & 9,843610671 \\
\hline mart_maurici & mart_maurici & Colombia & Other & 10,34482759 & 9,342393755 & 9,843610671 \\
\hline $\operatorname{cgt} 003$ & cgt003 & Colombia & Other & 3,448275862 & 13,31073411 & 8,379504987 \\
\hline onu & onu & Colombia & Other & 3,448275862 & 13,31073411 & 8,379504987 \\
\hline RamonRguezA & RamonRguezA & Colombia & NGO & 3,448275862 & 13,31073411 & 8,379504987 \\
\hline UnidadVictimas & UnidadVictimas & Colombia & NGO & 3,448275862 & 13,31073411 & 8,379504987 \\
\hline dalilatienda_18 & dalilatienda_18 & Colombia & Other & 6,896551724 & 9,342393755 & 8,11947274 \\
\hline fcomarquezv & fcomarquezv & Colombia & Other & 6,896551724 & 9,342393755 & 8,11947274 \\
\hline
\end{tabular}

Tabel 12

Rekap Excel dari Hasil Export Table Gephi

\begin{tabular}{|c|c|c|c|c|c|}
\hline Id & Label & Country & Cluster & Level of Influend - & Level of Intere: - \\
\hline HiroshiWago & HiroshiWago & Colombia & Gov & 6,896551724 & 9,342393755 \\
\hline julian_herbert & julian_herbert & Colombia & Mass Media & 6,896551724 & 9,342393755 \\
\hline nubesuavecita & nubesuavecita & Colombia & Other & 6,896551724 & 9,342393755 \\
\hline Pabuit & Pabuit & Colombia & Other & 6,896551724 & 9,342393755 \\
\hline sylviageorgina & sylviageorgina & Colombia & Mass Media & 6,896551724 & 9,342393755 \\
\hline villegasjacinto & villegasjacinto & Colombia & Other & 6,896551724 & 9,342393755 \\
\hline yolandacaon 2 & yolandacaon2 & Colombia & Other & 6,896551724 & 9,342393755 \\
\hline A_delPacifico & A_delPacifico & Colombia & NGO & 3,448275862 & 11,98743566 \\
\hline allamand & allamand & Chile & Gov & 3,448275862 & 11,98743566 \\
\hline Minrel_Chile & Minrel_Chile & Chile & Gov & 3,448275862 & 11,98743566 \\
\hline ACNUR_CostaRica & ACNUR_CostaRica & Costa Rica & NGO & 3,448275862 & 10,9300409 \\
\hline CeDemocratico & CeDemocratico & Colombia & Gov & 3,448275862 & 10,9300409 \\
\hline CiprianoArmente & CiprianoArmente & Colombia & Other & 3,448275862 & 10,9300409 \\
\hline CRcancilleria & CRcancilleria & Costa Rica & Gov & 3,448275862 & 10,9300409 \\
\hline dw_espanol & dw_espanol & German & Mass Media & 3,448275862 & 10,9300409 \\
\hline E_AsteteR & E_AsteteR & Peru & Gov & 3,448275862 & 10,9300409 \\
\hline Nessnio & Nessnio & Argentina & Other & 3,448275862 & 10,9300409 \\
\hline TecnoquimLtda & TecnoquimLtda & Colombia & Other & 3,448275862 & 10,9300409 \\
\hline UEenCostaRica & UEenCostaRica & Costa Rica & NGO & 3,448275862 & 10,9300409 \\
\hline ACNUR_Venezuela & a ACNUR_Venezuela & Venezuela & NGO & 3,448275862 & 10,47598314 \\
\hline ACNURamericas & ACNURamericas & Latin America & NGO & 3,448275862 & 10,47598314 \\
\hline ACNURSuramerica & ACNURSuramerica & Colombia & NGO & 3,448275862 & 10,47598314 \\
\hline AntonioSanguino & AntonioSanguino & Colombia & Gov & 3,448275862 & 10,47598314 \\
\hline CathyJuvinao & CathyJuvinao & Colombia & Gov & 3,448275862 & 10,47598314 \\
\hline DanieISamperO & DanielSamperO & Colombia & Other & 3,448275862 & 10,47598314 \\
\hline MafeCarrascal & MafeCarrascal & Colombia & Other & 3,448275862 & 10,47598314 \\
\hline OIMColombia & OIMColombia & Colombia & NGO & 3,448275862 & 10,47598314 \\
\hline SenadoGovCo & SenadoGovCo & Colombia & Gov & 3,448275862 & 10,47598314 \\
\hline
\end{tabular}

Tabel 13

Rekap Excel dari Hasil Export Table Gephi 
Penerapan Analisis Jejaring Sosial dalam Mengetahui Kekuatan Diplomasi Digital Indonesia di Kawasan Amerika Selatan

\begin{tabular}{|c|c|c|c|c|c|c|}
\hline - & Label & Country & Cluster & Level of Influend - & Level of Intere: - & Digital Diplomacy Ind .1 \\
\hline antiguagov & antiguagov & Antigua and Barbu & Gov & 3,448275862 & 10,33447884 & 6,891377353 \\
\hline ARGenOEA & ARGenOEA & Argentina & Gov & 3,448275862 & 10,33447884 & 6,891377353 \\
\hline BoliviaOEA & BoliviaOEA & Bolivia & Gov & 3,448275862 & 10,33447884 & 6,891377353 \\
\hline CafeconVozNi & CafeconVozNi & Colombia & Mass Media & 3,448275862 & 10,33447884 & 6,891377353 \\
\hline DonBendecido & DonBendecido & Colombia & Other & 3,448275862 & 10,33447884 & 6,891377353 \\
\hline elcaminante1982 & elcaminante1982 & Colombia & Other & 3,448275862 & 10,33447884 & 6,891377353 \\
\hline elovgon & elovgon & Colombia & Other & 3,448275862 & 10,33447884 & 6,891377353 \\
\hline jquinter 65 & jquintero65 & Colombia & Other & 3,448275862 & 10,33447884 & 6,891377353 \\
\hline LEONSK05134309 & LEONSK05134309 & Colombia & Other & 3,448275862 & 10,33447884 & 6,891377353 \\
\hline LeonSterimberg & LeonSterimberg & Colombia & Other & 3,448275862 & 10,33447884 & 6,891377353 \\
\hline MFABelize & MFABelize & Belize & Gov & 3,448275862 & 10,33447884 & 6,891377353 \\
\hline MRE_Bolivia & MRE_Bolivia & Bolivia & Gov & 3,448275862 & 10,33447884 & 6,891377353 \\
\hline OEA_BR & OEA_BR & USA & NGO & 3,448275862 & 10,33447884 & 6,891377353 \\
\hline PlazaPoncho & PlazaPoncho & Colombia & Other & 3,448275862 & 10,33447884 & 6,891377353 \\
\hline PTiburona & PTiburona & Colombia & Mass Media & 3,448275862 & 10,33447884 & 6,891377353 \\
\hline SelwinHart & SelwinHart & Colombia & Other & 3,448275862 & 10,33447884 & 6,891377353 \\
\hline argemiro1963 & argemiro1963 & Colombia & Other & 3,448275862 & 9,342393755 & 6,395334809 \\
\hline DannyMateus2 & DannyMateus2 & Colombia & Other & 3,448275862 & 9,342393755 & 6,395334809 \\
\hline DavidSantana88 & DavidSantana88 & Colombia & Other & 3,448275862 & 9,342393755 & 6,395334809 \\
\hline edharepe & edharepe & Colombia & Other & 3,448275862 & 9,342393755 & 6,395334809 \\
\hline ewallacta & ewallacta & Colombia & Mass Media & 3,448275862 & 9,342393755 & 6,395334809 \\
\hline Exiliomiami2 & Exiliomiami2 & Colombia & Other & 3,448275862 & 9,342393755 & 6,395334809 \\
\hline hectorapa84 & hectorapa84 & Colombia & Other & 3,448275862 & 9,342393755 & 6,395334809 \\
\hline herrera_miller & herrera_miller & Colombia & Other & 3,448275862 & 9,342393755 & 6,395334809 \\
\hline molina_elorza & molina_elorza & Colombia & Other & 3,448275862 & 9,342393755 & 6,395334809 \\
\hline OskarHernndezO & OskarHernndezO & Colombia & Other & 3,448275862 & 9,342393755 & 6,395334809 \\
\hline PhillipsLM & PhillipsLM & Colombia & Other & 3,448275862 & 9,342393755 & 6,395334809 \\
\hline PYS_Proyectos & PYS_Proyectos & Colombia & Other & 3,448275862 & 9,342393755 & 6,395334809 \\
\hline
\end{tabular}

Tabel 14

Rekap Excel dari Hasil Export Table Gephi

\begin{tabular}{|c|c|c|c|c|c|c|}
\hline Id & Label & Country & Cluster & Level of Influend - & Level of Intere: - & Digital Diplomacy Ind $v^{+}$ \\
\hline rubevarc & rubevarc & Colombia & Other & 3,448275862 & 9,342393755 & 6,395334809 \\
\hline wparra1974 & wparra1974 & Colombia & Other & 3,448275862 & 9,342393755 & 6,395334809 \\
\hline
\end{tabular}

Tabel 15

Rekap Excel dari Hasil Export Table Gephi

Kemudian penulis juga mencoba Fruchterman Reingold layout, dengan cara pilih pada tab layout.

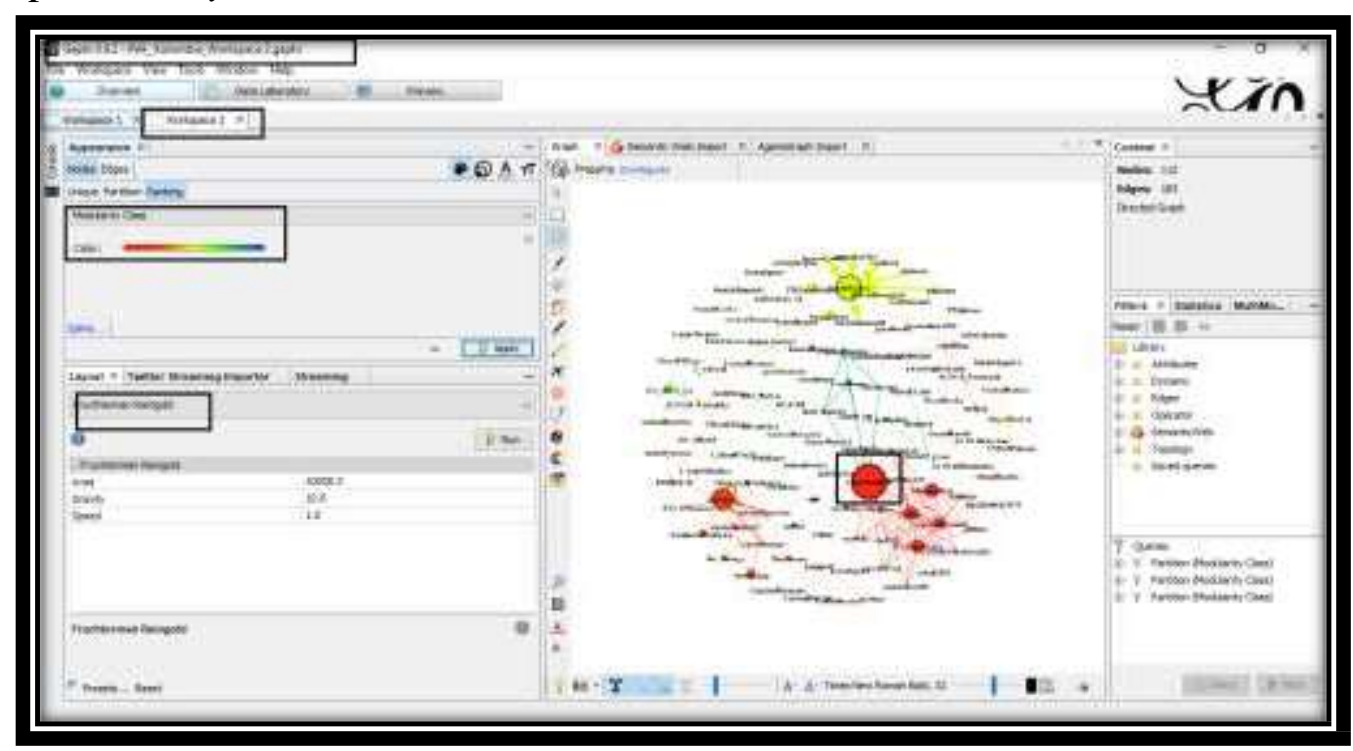

Gambar 16

Gephi Kekuatan Diplomasi Digital antara Indonesia dan Kolombia dengan Fruchterman

Reingold layout 


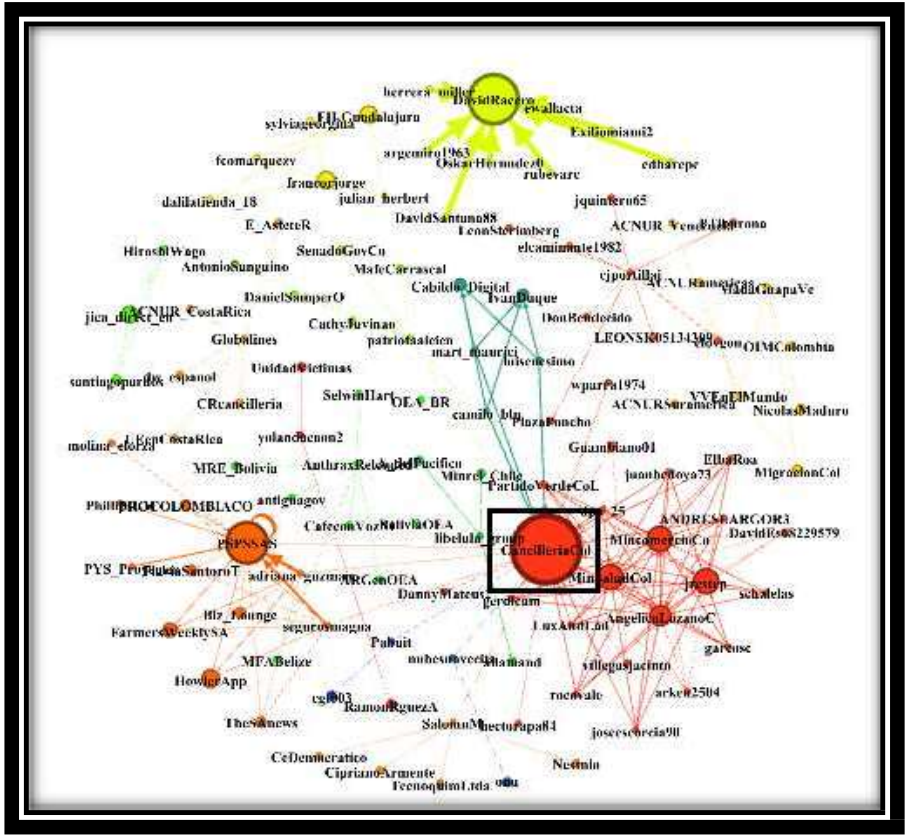

\section{Gambar 17}

Gephi Kekuatan Diplomasi Digital antara Indonesia dan Kolombia dengan Fruchterman Reingold layout

\section{Hasil Analisa}

\begin{tabular}{|c|c|c|c|c|c|c|}
\hline$F$ & Label & Country & - Cluster & - Level of Influence - & Level of Interest & Digital Diplomacy Index $>1$ \\
\hline Cancilleriacol & CancilleriaCol & Colombia & Gov & 100 & 100 & 100 \\
\hline PSPSSAS & PSPSSAS & Colombia & Other & 51,72413793 & 60,78153913 & 56,25283853 \\
\hline DavidRacero & DavidRacero & Colombia & Gov & 27,5862069 & 72,85605436 & 50,22113063 \\
\hline AngelicaLozanoC & AngelicaLozanoC & Colombia & NGO & 58,62068966 & 30,17618063 & 44,39843514 \\
\hline irestrp & jrestrp & Colombia & Gov & 48,27586207 & 36,59052388 & 42,43319297 \\
\hline Mincomercioco & Mincomercioco & Colombia & Gov & 48,27586207 & 36,59052388 & 42,43319297 \\
\hline MinSaludCol & MinSaludCol & Colombia & Gov & 48,27586207 & 36,59052388 & 42,43319297 \\
\hline cjportillaj & cjportillaj & Colombia & Other & 34,48275862 & 9,342393755 & 21,91257619 \\
\hline FILGuadalajara & FILGuadalajara & Colombia & Mass Media & 13,79310345 & 25,22042016 & 19,5067618 \\
\hline francorjorge & francorjorge & Colombia & Other & 13,79310345 & 25,22042016 & 19,5067618 \\
\hline adriana_guzman & adriana_guzman & Colombia & Gov & 27,5862069 & 9,342393755 & 18,46430033 \\
\hline AnthraxReloaded & AnthraxReloaded & Colombia & Other & 27,5862069 & 9,342393755 & 18,46430033 \\
\hline segurosmagna & segurosmagna & Colombia & Mass Media & 27,5862069 & 9,342393755 & 18,46430033 \\
\hline HowlerApp & HowlerApp & Colombia & Other & 10,34482759 & 26,14564058 & 18,24523408 \\
\hline FarmersWeeklySA & FarmersWeeklySA & Colombia & Mass Media & 13,79310345 & 20,97995615 & 17,3865298 \\
\hline patriotaalcien & patriotaalcien & Colombia & Other & 24,13793103 & 9,342393755 & 16,74016239 \\
\hline VVEnEIMundo & VVEnEIMundo & Colombia & Other & 24,13793103 & 9,342393755 & 16,74016239 \\
\hline jica_direct_en & jica_direct_en & Japan & Mass Media & 6,896551724 & 24,6264131 & 15,76148241 \\
\hline PartidoVerdeCoL & PartidoVerdeCoL & Colombia & Mass Media & 20,68965517 & 10,47598314 & 15,58281916 \\
\hline Cabildo_Digital & Cabildo_Digital & Colombia & Other & 10,34482759 & 17,28062946 & 13,81272852 \\
\hline IvanDuque & IvanDuque & Colombia & Gov & 10,34482759 & 17,28062946 & 13,81272852 \\
\hline ANDRESLARGOR3 & ANDRESLARGOR3 & Colombia & Other & 17,24137931 & 9,342393755 & 13,29188653 \\
\hline arken 2504 & arken 2504 & Colombia & Other & 17,24137931 & 9,342393755 & 13,29188653 \\
\hline DavidEs68229579 & DavidEs68229579 & Colombia & Other & 17,24137931 & 9,342393755 & 13,29188653 \\
\hline dpa_25 & dpa_25 & Colombia & Other & 17,24137931 & 9,342393755 & 13,29188653 \\
\hline ElbaRoa & ElbaRoa & Colombia & Other & 17,24137931 & 9,342393755 & 13,29188653 \\
\hline
\end{tabular}

Tabel 16

\section{Rekap Excel dari Hasil Export Table Gephi}

Melalui tabel 14 dapat dilihat bahwa, pengaruh CancilleriaCol (Akun twitter resmi Kedutaan Besar Kolombia di Indonesia) jauh lebih besar dibandingkan dengan IndonesiainCOL (Akun twitter resmi Kedutaan Besar Indonesia di Kolombia). Hal ini juga dapat dilihat pada, besarnya level of influence, level of interest serta digital diplomacy index. Dibuktikan juga dengan nodes dan edges seperti berikut. 


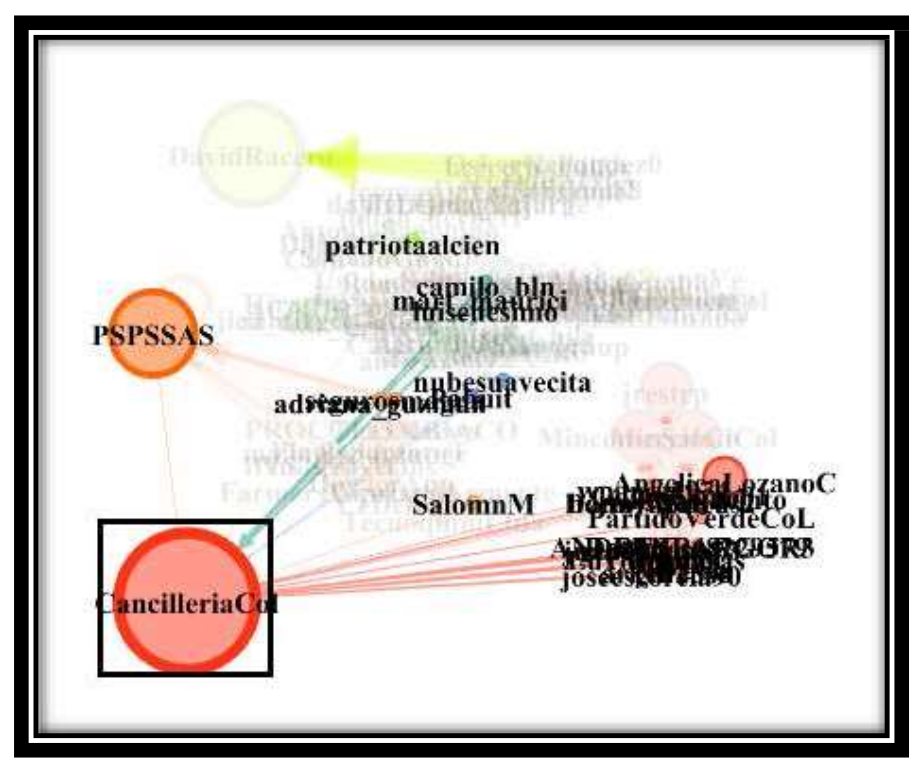

Gambar 18

Gephi Kekuatan Diplomasi Digital antara Indonesia dan Kolombia dengan circle park layout

Dan jika dilakukan filter berdasarkan partition, maka hasil untuk CancilleriaARG (Kedutaan Besar Argentina dan Paraguay di Indonesia) adalah sebagai berikut.

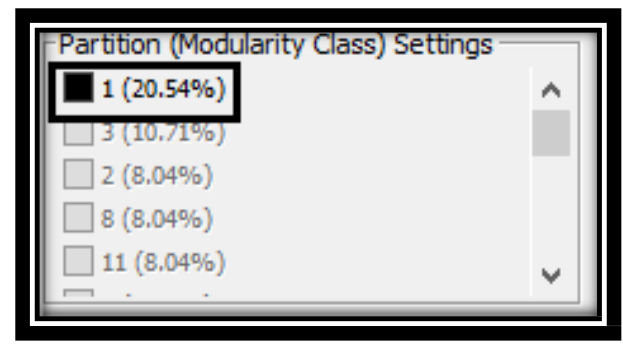

Gambar 19

Gephi Kekuatan Diplomasi Digital antara Indonesia dan Kolombia dengan filter modularity class (node)

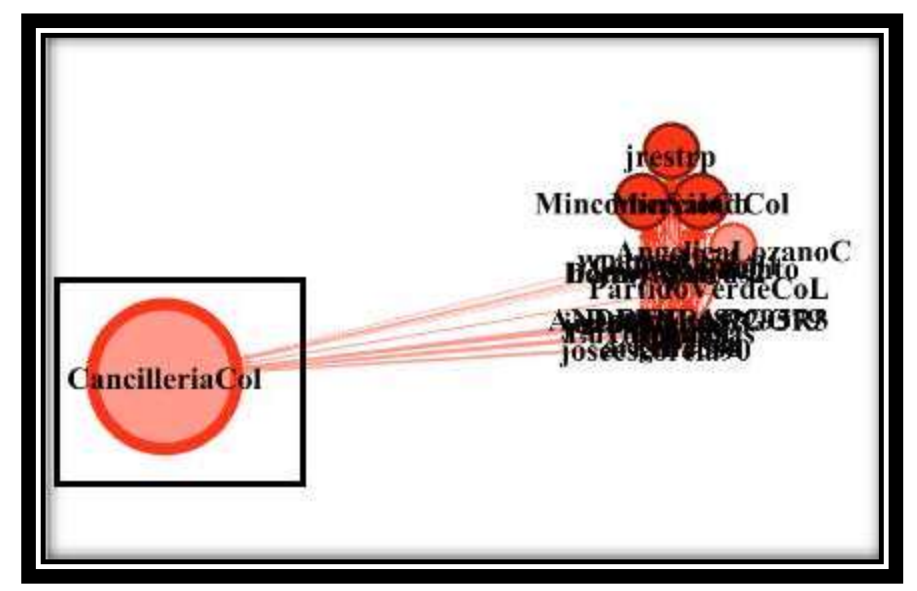

Gambar 20

Gephi Kekuatan Diplomasi Digital antara Indonesia dan Kolombia dengan filter modularity class (node) 


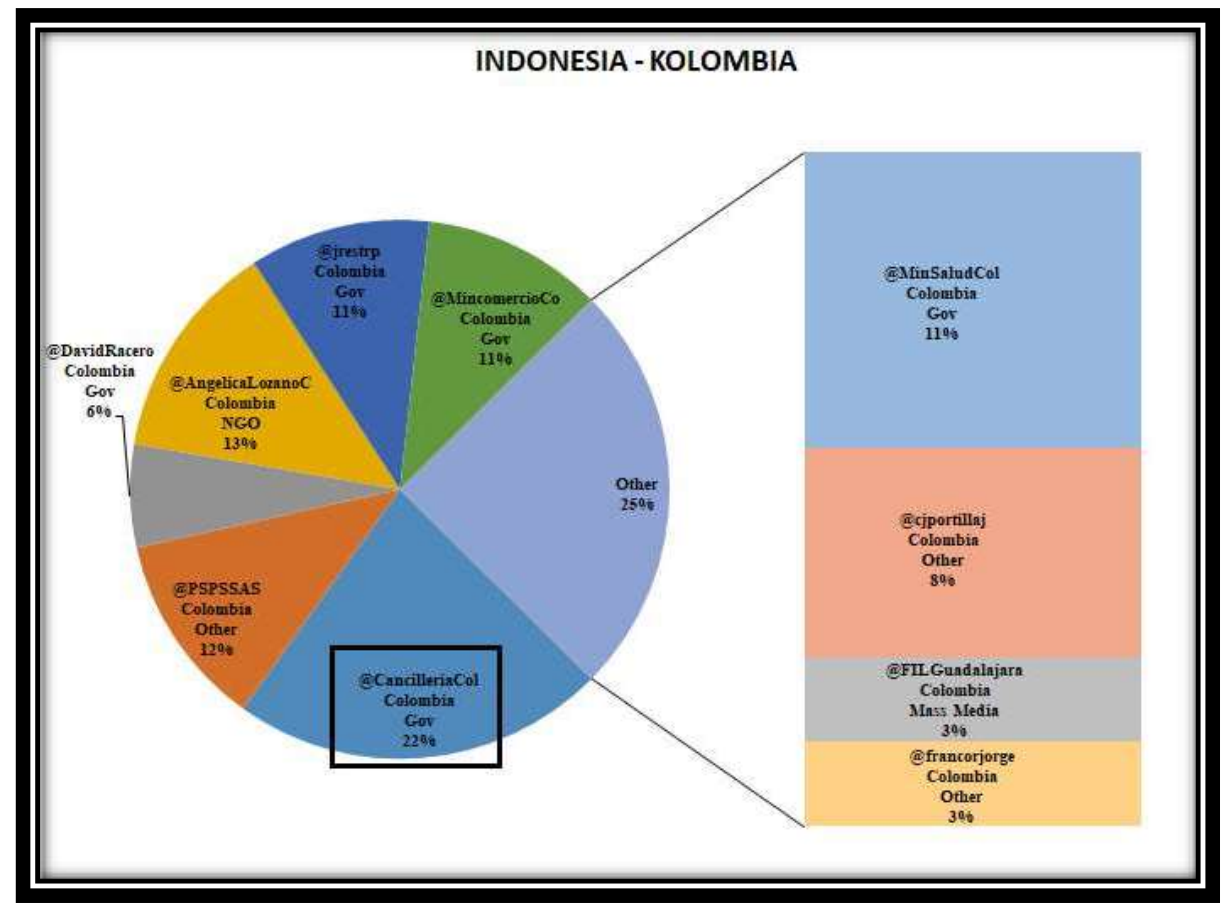

Gambar 21

Data hasil analisa kekuatan diplomasi digital Indonesia dengan Amerika Selatan

Dan jika dilihat dari country, Kolombia lebih unggul dalam hal studi kasus diplomasi digital ini. Serta jika dilihat dari cluster, peran pemerintah dan NGO condong lebih besar pengaruhnya, meskipun aktor yang terlibat atau nodes lebih banyak peran other atau masyarakat digital. Kemudian, country atau parties yang terlibat yakni Argentina, Antigua dan Barbuda, Belize, Bolivia, Chile, Kolombia, Jerman, Kostarika, Jepang, Amerika Latin, Peru, Afrika Selatan, Amerika Serikat dan Venezuela.

\section{Ekuador}

a. Akun Twitter Resmi

Tidak ada data ketika grabbing data.

$\rightarrow$ @QuitoKbri (Akun resmi Kedutaan Besar Indonesia di Ekuador) .

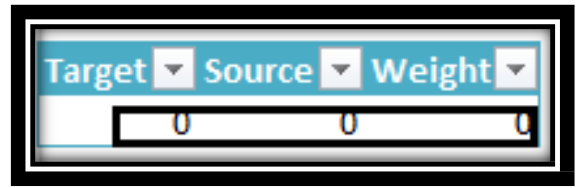

Tabel 17

\section{French Guiana}

Akun twitter tidak aktif, grabbing data kosong

a. Akun Twitter Resmi

$\rightarrow$ @CtdeGuyane (Akun twitter resmi the Territorial Collectivity of Guyana) dan @ KBRI_Paris (Akun twitter resmi Kedutaan Besar Indonesia di Perancis). French Guiana merupakan wilayah Prancis di benua Amerika, tidak dimasukkan dalam perhitungan secara khusus, karena kebijakan diplomasinya bergantung Prancis (métropole) di benua Eropa (Britannica, 1998). 


\section{b. Analisa Data}

Untuk dapat melakukan analisa ini, penulis melakukan grabbing data melalui microsoft excel 2016, lalu setelah data didapat dari kedua akun twitter resmi tersebut, data selanjutnya di merge atau combine masih dalam microsoft excel 2016, kemudian hapus kolom selain target, source dan weight, pastikan jika ada baris dari kolom weight yang bernilai 0 , ubah terlebih dahulu menjadi 1 . Kemudian save as dengan format xls. Kemudian buka Gephi 0.9.2, pertama-tama, jalankan plugins yang ada pada tab overview kemudian masuk ke tab data laboratory, klik import spreadsheet lalu pilih file excel yang sudah kita dapat dari hasil grabbing data yang dilakukan, lalu jika berhasil, copy data to other column dan pilih ID, kemudian Label. Setelah itu, pindah lagi ke tab overview. Pada bagian appearance untuk color, pilih ranking berdasarkan degree serta untuk size, pilih ranking berdasarkan PageRank. Kemudian apply. Selanjutnya, pada kolom layout, pilih circle park layout. Juga masukan credentials pada bagian tab twitter streaming importer.

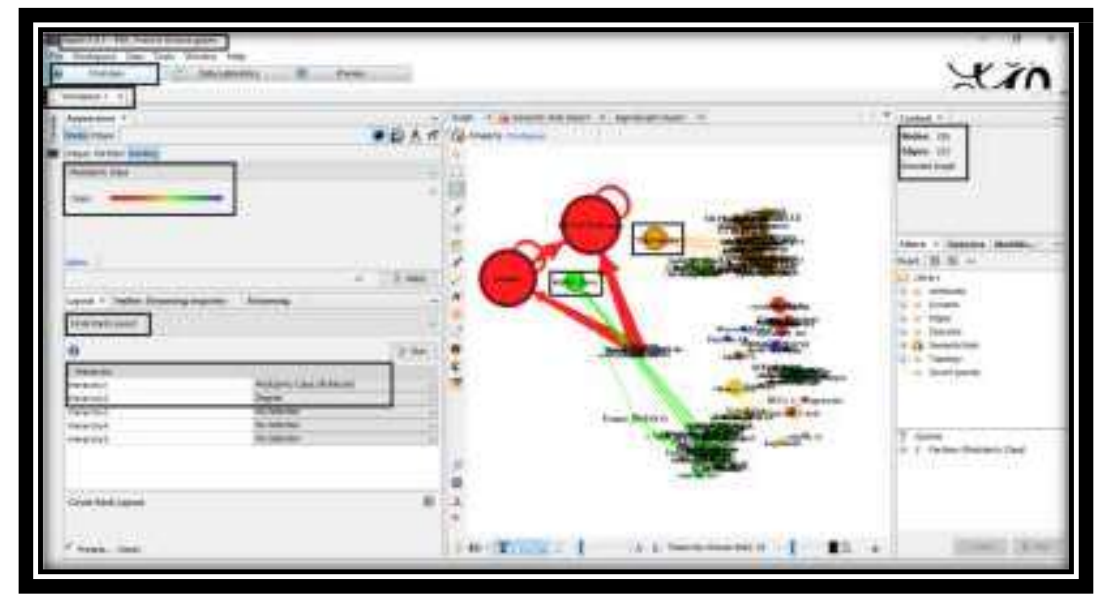

Gambar 22

Gephi Kekuatan Diplomasi Digital antara Indonesia dan French Guiana dengan circle park layout

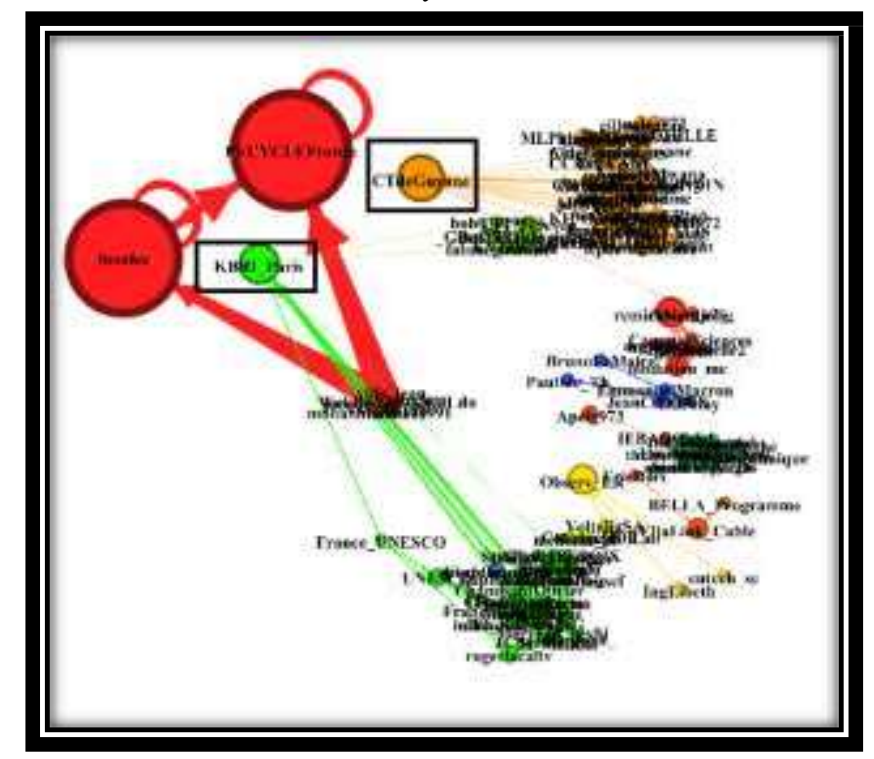

Gambar 23

Gephi Kekuatan Diplomasi Digital antara Indonesia dan French Guiana dengan circle park 


\section{layout}

Kemudian, pilih lagi tab data laboratory, lalu pilih export table. Kemudian buka file tersebut dengan microsoft excel 2016 dan lakukan normalize, kemudian tambahkan kolom country, cluster, level of influence, level of interest, serta digital diplomacy index. Dimana cluster disini terbagi menjadi government, NGO, mass media dan other.

\begin{tabular}{|c|c|c|c|c|c|c|}
\hline In & F Lubed & - Counti & - Chaser :- & Lecel ar Inllouart & Lewel ur hateres - & Dipital Dipbormace Inde 2 \\
\hline PVCYCLEFrauce & PVCYCLEFrance & France & NGO & 40.90909091 & 100 & 70,45454545 \\
\hline Screlec & Screlec & France & NGO & 40,90909091 & 96,4389965 & 68.6740437 \\
\hline CTdeGuvane & CTdeGuyane & France & Gay & 86,36363636 & 36,05942362 & 61,21152999 \\
\hline GropaneActs & GryaneActs & France & Mass Media & 100 & 9,037927195 & 54,5189636 \\
\hline Info Java & Info Java. & Indonesia & Mass Media & 90,90909091 & 5.108972124 & 48,03903152 \\
\hline KBPII_Paris & KBRI Paris & Indeoesia & Gov & 54,54545455 & 30,35078392 & 42,44811923 \\
\hline aucant & aucant & France & Other & 63,53636364 & 4,722592812 & 34,17947822 \\
\hline Jereng73 & Jerem973 & France & Other & 59,09090909 & 5,356551745 & 3222373042 \\
\hline rwk-973 & twk973 & France & Other & 40,90909091 & 5,062497116 & 23.28579401 \\
\hline RaphaelGerad17 & RaphaeiGerard17 & France & Gov & 40,90909091 & 4,722592812 & $22,8158+186$ \\
\hline Faridagtit & Fanidarjt & France & Otber & 40,90909091 & 4,722592812 & 22,81384180 \\
\hline Geeroms Monique & Geeroms Monique & France & Orher & $+0,90909091$ & 4.722592812 & 22.81584186 \\
\hline isabelarthe & isabelartbe & France & Other & 4090909091 & 4,722592812 & 22,81584186 \\
\hline forsdation $m e$ & fondation me & France & Other & 31,81319182 & 13,55498459 & 2268653321 \\
\hline reniremontjoly & reariremontjoly & France & Other & 22,72727273 & 21,06305493 & 21,89517883 \\
\hline fabreeglantine & folbreeglantine & France & Other & 36,36363036 & 4,722592812 & 2054311459 \\
\hline outremers 360 & outremers 360 & France & Mass Mledia & 31,81818182 & 8,996800112 & 20,40749097 \\
\hline GeotgesP atient & Georges Patienz & France & Gov & 3181818182 & $\$, 996800112$ & 20,40749097 \\
\hline ACCDOM asso & $\mathrm{ACCDOM}$ asso & France & NGO & 31,81318182 & B.996800112 & 20.40749097 \\
\hline RpheAlesandre & RpheAlexandre & France & Gov & 31,81818182 & 8,996800112 & 20,40749097 \\
\hline Obsery ER & Observ ER & France & Mass Media & 18,18181818 & 20,78121395 & 19,48151607 \\
\hline bob03929586 & bob0 03929586 & France & Other & 31,81818182 & 3,224142001 & $18 \leq 2116221$ \\
\hline
\end{tabular}

Tabel 18

Rekap Excel dari Hasil Export Table Gephi

\begin{tabular}{|c|c|c|c|c|c|c|}
\hline Iar & 'Labe! & - Country - & Cluser & 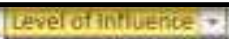 & tevel of hinterest - & Oigital oiplomacy labex a. \\
\hline Ginofiom972 & Gincfiom 972 & France & Oaher & 31,81818182 & 5,088724158 & 18,45345299 \\
\hline AndielieMoote & Andjelie Moote & France & Other & 31,81818182 & 4,722592812 & 18,2703873 \\
\hline 973 Lesley & 973Lesley & France & Other & 32,81818182 & 4,722592812 & $18,2703873 !$ \\
\hline BBACTALIS & JBACTALIS & France & Oaher: & 31,81818182 & 4,722592812 & 18,27038731 \\
\hline Prefet973 & Prefet 973 & France & $\mathrm{Gev}$ & 27,27272727 & 7,677724168 & $17,47 \leq 22572$ \\
\hline besoutremer & lesoutrenter & France & Gov & 27,27272727 & 7,677724168 & 17,475222572 \\
\hline rogerlacsury & rogerlacasy. & France & Gov & 22,72727273 & 10,4482852 & 16,58777896 \\
\hline UNESCO & UNESCO & International & Other & 22,72727273 & 10.4482852 & 16587777896 \\
\hline KHAMOUN974 & KHAMOUN974 & France & Other & 27,27272727 & 4,722592812 & 15,99766004 \\
\hline NOUGWIYANN & NOUGWTYANN & France & Ocher & 27,27272727 & 4,722592812 & 15,99766004 \\
\hline Carine02116201 & Carine 02116201 & France & Other & 27,27272727 & 4,722592812 & 15,99760004 \\
\hline NVirgaflis. & NVargaffie & France & Other & 2272723273 & 4,722592812 & 13,72493277 \\
\hline AirVacancesFR & AirVacancesER & France & Gov & 22,72327273 & 4,722592812 & 13,72493277 \\
\hline jerstan & jerstasa & France & Other & $18,1818: 818$ & 5.862113932 & 12,02196600 \\
\hline MedefGaryane & MedefGuyane & France & Other & 13,63636364 & 9,884543239 & $1 \mathrm{t}, 76045344$ \\
\hline ARDI GDI & ARDI_GDI & France & Gov & 18,18151818 & 4,722592812 & 11,4522055 \\
\hline DuFelay & DuFelay & France & Other & 18,18181818 & 4,722592812 & $\$ 1.4522055$ \\
\hline Ellalink Cabsle & EllaLinik_Cable & France & Other & 9.090909091 & 12,75140183 & 10,92115546 \\
\hline doctroptard & doctroptard & France & Other & 13.63636364 & 6,000727648 & 9,848545642 \\
\hline quaibranty & quaibranly & France & Mass Media & 13,63636364 & 6,000727648 & 9,848345642 \\
\hline nikosaliagas & nikosab̆agas & France & Mass Media & 13,63636364 & 6,060727648 & 9,848545642 \\
\hline theborneopost & theborneopost & France & Mass Media & 13,63636364 & 6,060727648 & 9.848545642 \\
\hline IFI Indonesia & IFI Indonesia & Indonesia & Other & 13,63636364 & 6,060727648 & 9,84854564 \\
\hline IDFR. & IDFR & France & Otber & 13,63636364 & 6,060727648 & $9,8+8545642$ \\
\hline
\end{tabular}

Tabel 19

Rekap Excel dari Hasil Export Table Gephi 
Penerapan Analisis Jejaring Sosial dalam Mengetahui Kekuatan Diplomasi Digital Indonesia di Kawasan Amerika Selatan

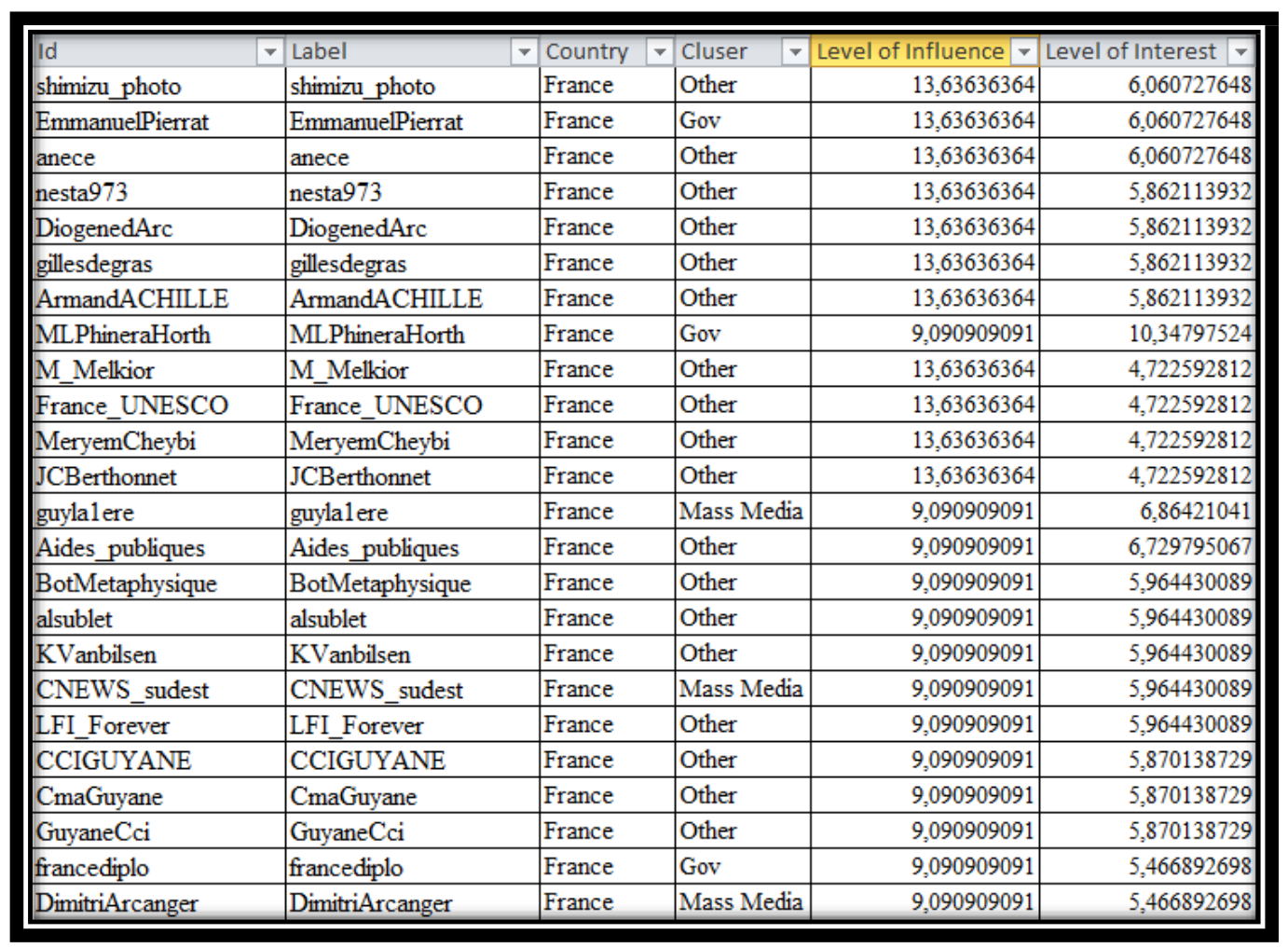

Tabel 20

Rekap Excel dari Hasil Export Table Gephi

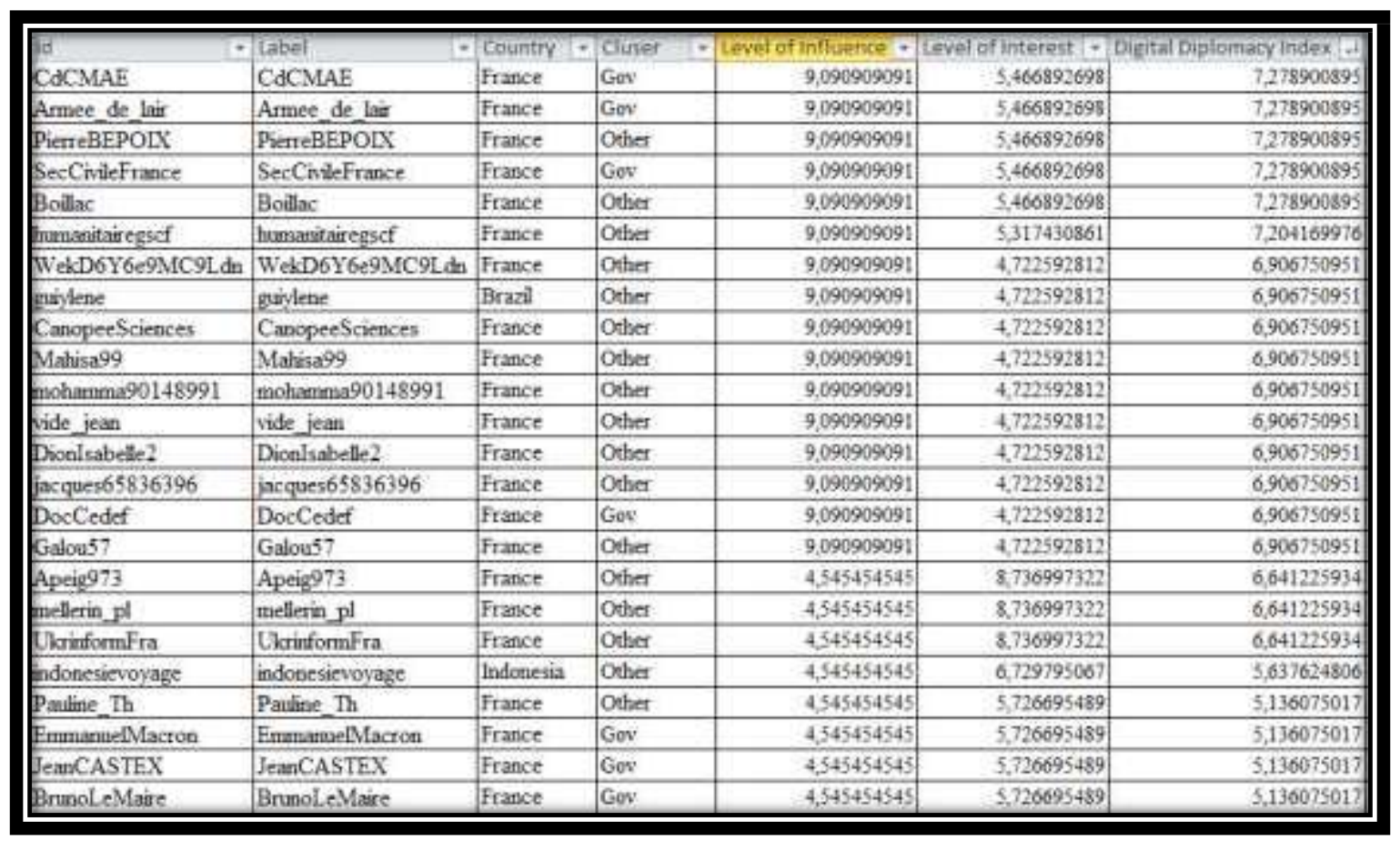

Tabel 21

Rekap Excel dari Hasil Export Table Gephi 


\begin{tabular}{|c|c|c|c|c|c|c|}
\hline (iif & 7tabel & 9 Cobutsy & Courer & Levoref linfuereo : & Levertar bithent:- & 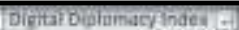 \\
\hline lacgurane & acoguyene & France & Cov & +54545455 & 5526075974 & 3.035765050 \\
\hline Univgurane & wivgryme & France & Woter & 4,545454545 & 5,576075574 & 5.035765059 \\
\hline voyene ats & gurane ctr & France & Other & 4,545454545 & 5526075574 & 5.035765699 \\
\hline roodegurane: & roodezuyane & France & Obler & 455454545 & 5536035574 & 2035765059 \\
\hline fronceguyase & fraceguyme & Francer & Masi Media & $4,545+54545$ & S.5050055574 & $5.035576505 \%$ \\
\hline chog 973 & dhog 973 & France & Othe & $4,545+545+5$ & 539166023 & 4560557381 \\
\hline gri gurane & ais pyoe & France & Gov & 4545454545 & 5,39166023 & 4965557381 \\
\hline CHCoreme973 & CHACayenne973 & France. & Celor. & $4,545+54543$ & 5,3916003 & 4965557383 \\
\hline Cillets Jannes & Gilets Jaunes & France & Man Medta &,+ 545454545 & $52241+2601$ & $485+79557$ \\
\hline FranceladcartalD & Francelalartald & France & Gov & 4,545454545 & 5,796822181 & 4671138363 \\
\hline Chanburdotinier & Chambardofrier & France & Gov & $4,54545+545$ & 4,796822181 & 4671138363 \\
\hline IFI Sby & in sby & Introensia & Ober & 454545455 & 4796822181 & 4671138361 \\
\hline IFI Yonakicita & IfI Yoryakarta & Todiceetia & Otbet & 4,545454545 & 4,796822181 & 407113363 \\
\hline III BANDUNO & II BMNDUNSC & Indouria & Othen & $+345+545+5$ & 4,706822181 & 4672138563 \\
\hline IICC] & FOCI & tratonesis & Other & 4545454545 & 4.796832181 & 4671135361 \\
\hline ThasaGOVINDIN & ThanoONINDN & France. & Osber & $4,545+545,45$ & 4,72992812 & $460+08367$ \\
\hline NinDaraMrana & NoDataMwma & Franct & Other & 4.54545453 & 4722592812 & 7034023679 \\
\hline CoriaielcasbonenI & Corinnelcarbornal & France & Ohere & $4,5454545+5$ & 4722592812 & $+864+023670$ \\
\hline FBAOFficiel & IFBAOtficiel & France & Ohter &,$+ 54545+545$ & 4.722592812 & 4634023677 \\
\hline iemurcelint & jearceline & Frmate & Other & 454545445 & 4,722592812 & 463402367 \\
\hline EricDaì & EricDair & France & Otbet &,+ 545454545 & 4,722592912 & 4,034023078 \\
\hline BFLA. Proygam: & Min LA Programme & France & Othen & $+345+545+5$ & 4,722592812 & 4 40.403167 \\
\hline Ingl. Lubed & Int.beth & France & Other & 4545454545 & 4,722592812 & +634023679 \\
\hline Creader Lab & Creadev Lab & France. & कiber. & $+3454545+5$ & 4722599812 & $403+03367$ \\
\hline
\end{tabular}

Tabel 22

Rekap Excel dari Hasil Export Table Gephi

\begin{tabular}{|c|c|c|c|c|c|c|}
\hline E & Label & Countey $=$ & Cuset & Leverof intuente -9 & Leveror firefest o & Drataldiplemicy index $A$ \\
\hline VoltraliasA & VotraliasA & France & Other & 4.545454545 & 4,722592812 & 4,634023679 \\
\hline entech se & entech se & France & Other & 4,545454545 & 4,722592812 & 4,634023679 \\
\hline CooraceHDF & CooraceHDF & France & Other & 4,545454545 & 4,722592812 & 4,634023679 \\
\hline angod & ampul & France & Other & +545454545 &,+ 722592812 & 4,634023679 \\
\hline MayaGRanoe & MayaGRanoe & France & Other & $4,545+54545$ & 4,722392812 & 4,034023079 \\
\hline gofia sodarma & sotia modarma & Indotesia & Other & 4,545454545 & 4.722592812 & 4,634023679 \\
\hline sportuboctorapb & sportdoctorapb & Swrizerland & Other & 4,545454545 & 4,722592812 & 4,634023639 \\
\hline CRuschbarini & CRusdharini & Indoneria & Other & 4,545454545 & 4,722592812 & 4,634023679 \\
\hline
\end{tabular}

Tabel 24

Rekap Excel dari Hasil Export Table Gephi

Kemudian penulis juga mencoba Fruchterman Reingold layout, dengan cara pilih pada tab layout.

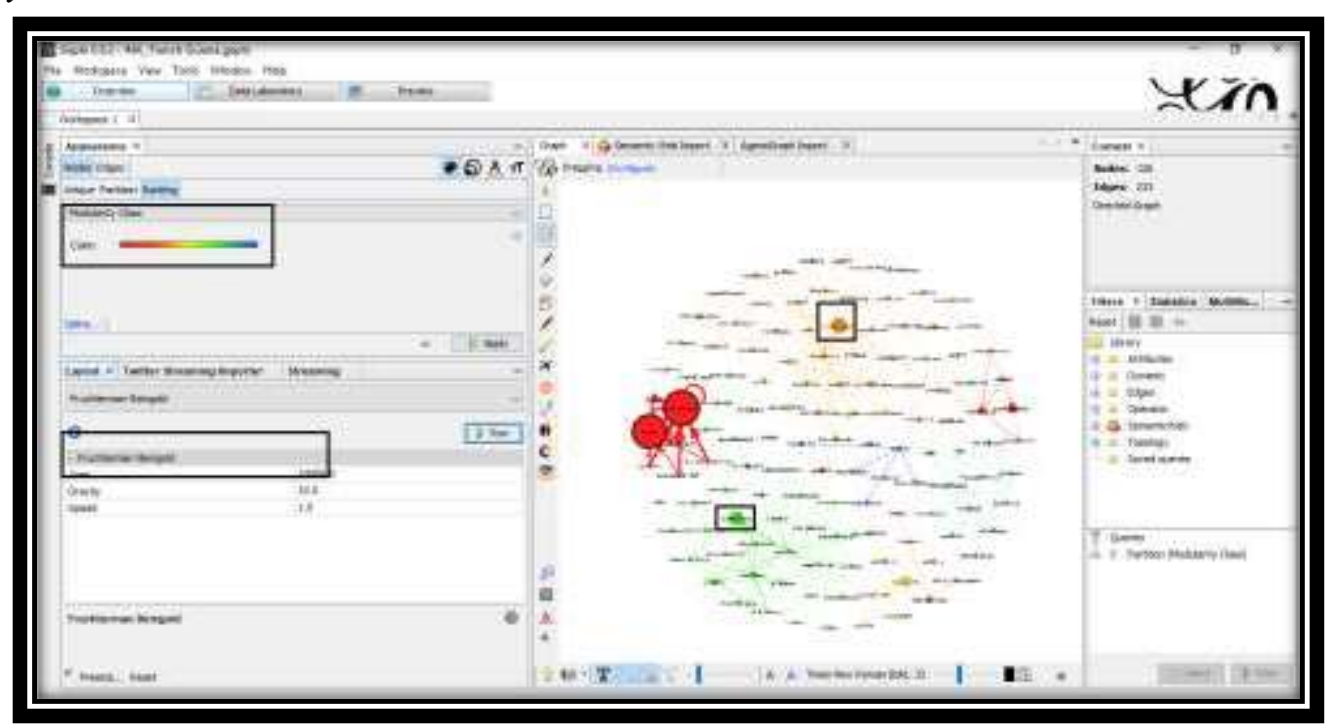

Gambar 25

Gephi Kekuatan Diplomasi Digital antara Indonesia dan French Guinia dengan Fruchterman Reingold layout 


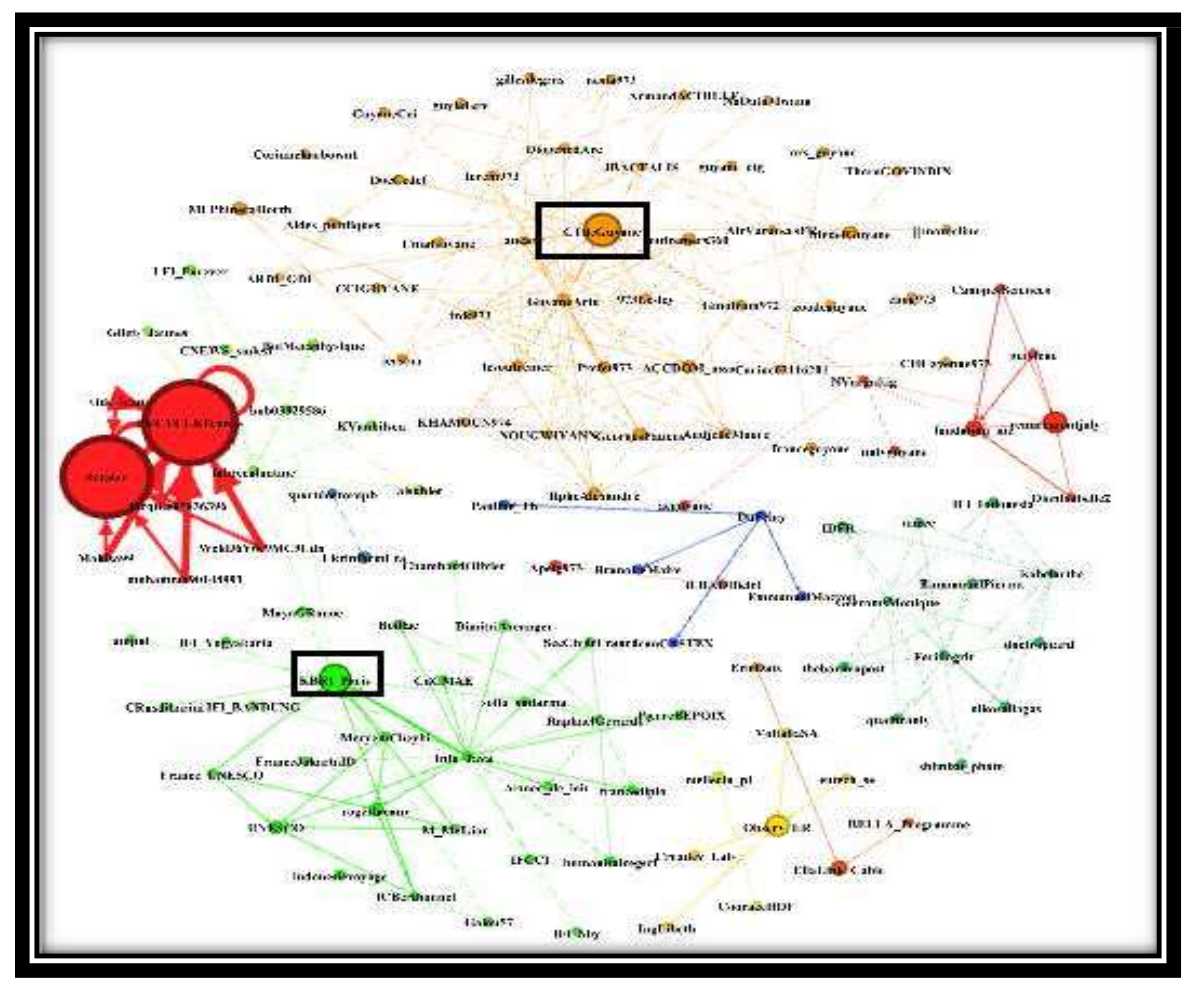

Gambar 26

Gephi Kekuatan Diplomasi Digital antara Indonesia dan French Guinia dengan Fruchterman Reingold layout

c. Hasil Analisa

\begin{tabular}{|c|c|c|c|c|c|c|}
\hline & & 8 & $y$ & exel ar liuta & Devetartiniverefo & 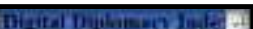 \\
\hline PVCYCI FFrance & PYCYCLEFrance & France & NGO & 40.90909091 & 100 & 70,45454545 \\
\hline Sareler & Saibe & France & $\mathrm{NCO}$ & 4090909091 & 99,4399965 & $65,074043 ?$ \\
\hline CTdeGurame & CTdeGryane & France & Gey & 86,30303036 & 3605942362 & 01,21152999 \\
\hline Guyine-Actu & GuraneActo & France & Mass Menta & TDण & 9037927195 & उड़ा890: \\
\hline Info Jave & linfo lesa & Indoneria & Mass Media & 9090909091 & 3,162972124 & 4803909152 \\
\hline KBRI Parts & KBRI Panis & indonesga & Gov. & 54,54545455 & 30,35078392 & 424481192 \\
\hline racar & aucart & Ftance & Other & 63,63636364 & 2,722592812 & $3+57947822$ \\
\hline Jerem 973 & Jerens 973 & France & Other & 3909090909 & 3,356551745 & 32,22373042 \\
\hline twolst3 & nok973 & France & Other & 20.90909091 & 5,00749716 & 2328579401 \\
\hline Raphasekerard17 & RaphaelGarard? & France & Gov: & 490909091 & 4,722592812 & 2281584180 \\
\hline Fanidngit & Faridagrt & France & Other & 6090909091 & 4722592812 & 2281584186 \\
\hline GedronsMortique & Geecons:Moriqas & France & Other & +090909091 & $\$, 722592812$ & 2281584186 \\
\hline Esalnelarthe & isabeharthe & France & Other & 40,99909091 & 4722592812 & 22,81584180 \\
\hline foodation me & fondation ins & France & Otber & 3181818182 & 13.55488459 & 22,69053321 \\
\hline Fenitemiotaiob: & temiremontjoly & France & Other & 22,72727273 & 21.06308493 & 21.89517883 \\
\hline fabree dertase & faldreeglantine & France & Other & 3636363636 & 4,722592812 & 20.54311459 \\
\hline outremer 360 & oxtremers 360 & France & Mass Media & 31,81318182 & 8996900112 & 20,40749097 \\
\hline GeorgesPatient & GeorgesPatient & France & Gov & 31,81818182 & 8996500112 & 20,40749097 \\
\hline ACCDONA asso & ACCDOM asso & France & NoO & 31,81818182 & 8596900112 & 20,40749097 \\
\hline Piphe/Nexandre & Rebellexandre & France. & Gow & 31,81818182 & 8,596900112 & 20,40749097 \\
\hline Obseav ER: & Observ ER & France & Mass Media & 1818181818 & $20,73 t 21399$ & 19.48151607 \\
\hline bob039295\$6 & bob03929586 & France & Other & 31.81818182 & 3224142601 & 18.52116221 \\
\hline
\end{tabular}

Tabel 21

Rekap Excel dari Hasil Export Table Gephi

Melalui tabel 22 dapat dilihat bahwa, pengaruh CtdeGuyane (Akun twitter resmi the Territorial Collectivity of Guyana) jauh lebih besar dibandingkan dengan dan @KBRI_Paris (Akun twitter resmi Kedutaan Besar Indonesia di Perancis). Hal ini juga dapat dilihat pada, besarnya level of influence, level of interest serta digital diplomacy index. Dibuktikan juga dengan nodes dan edges seperti berikut. 


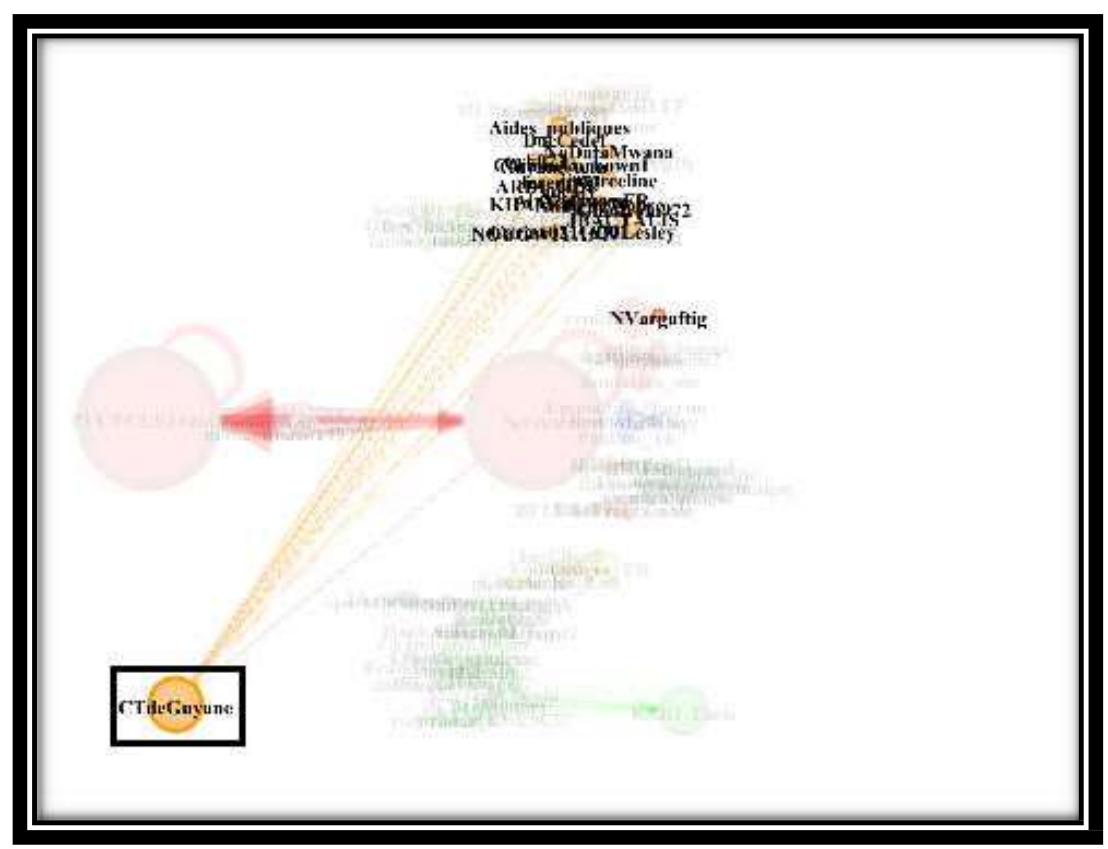

Gambar 27

Gephi Kekuatan Diplomasi Digital antara Indonesia dan French Guiana dengan circle park layout

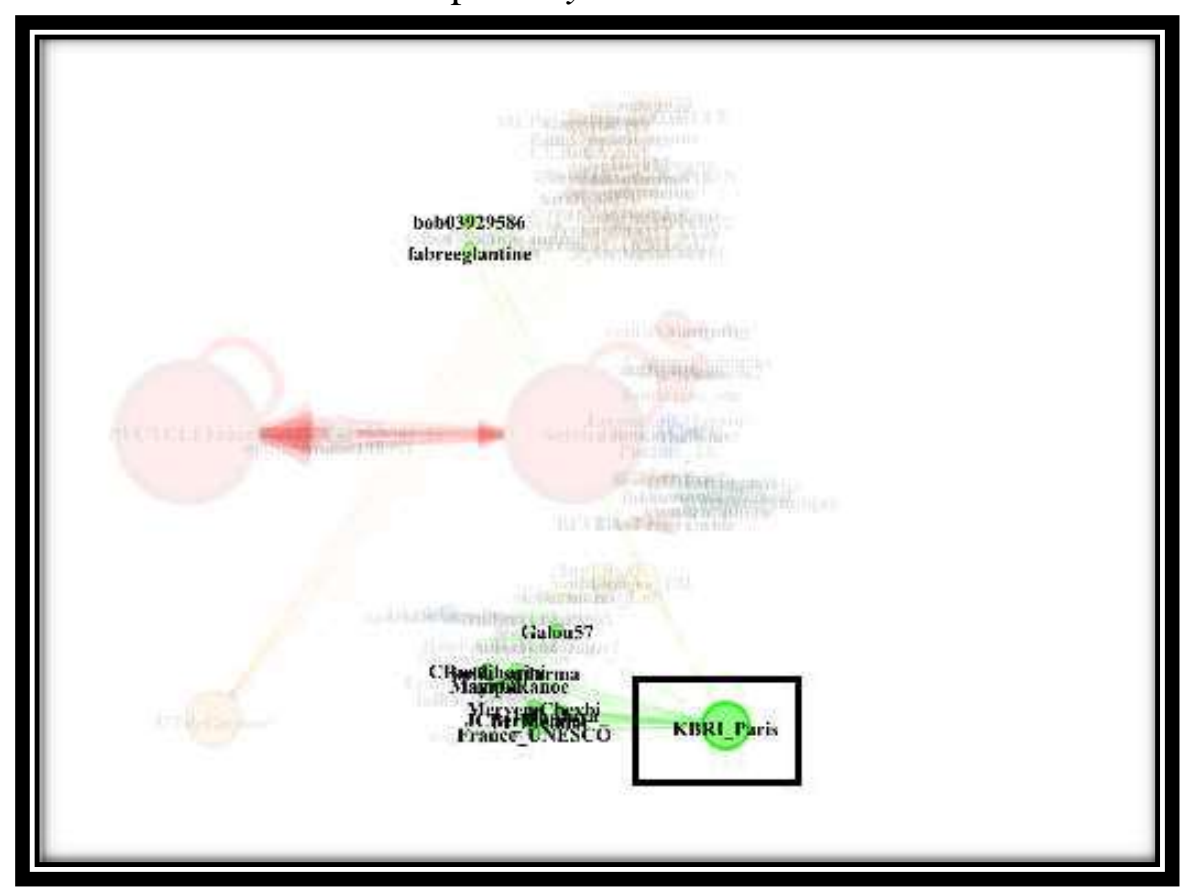

Gambar 28

Gephi Kekuatan Diplomasi Digital antara Indonesia dan French Guiana dengan circle park layout

Dan jika dilakukan filter berdasarkan partition, maka hasil untuk CtdeGuyane (Akun twitter resmi the Territorial Collectivity of Guyana) adalah sebagai berikut. 


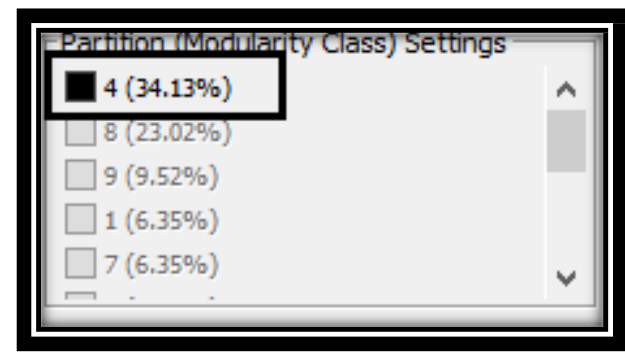

Gambar 29

Gephi Kekuatan Diplomasi Digital antara Indonesia dan Kolombia dengan filter modularity class (node)

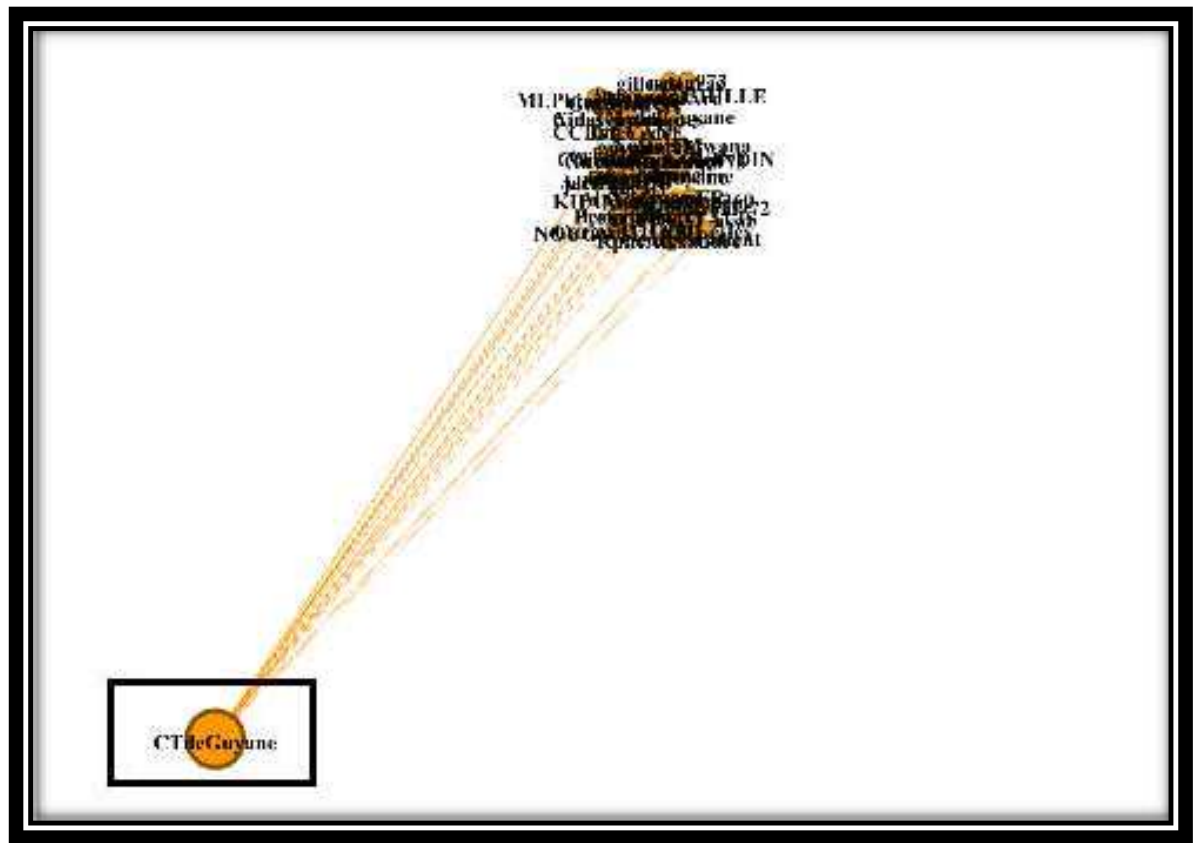

Gambar 30

Gephi Kekuatan Diplomasi Digital antara Indonesia dan French Guiana dengan filter modularity class (node)

Dan jika dilakukan filter berdasarkan partition, maka hasil untuk KBRI_Paris (Akun twitter resmi Kedutaan Besar Indonesia di Perancis).

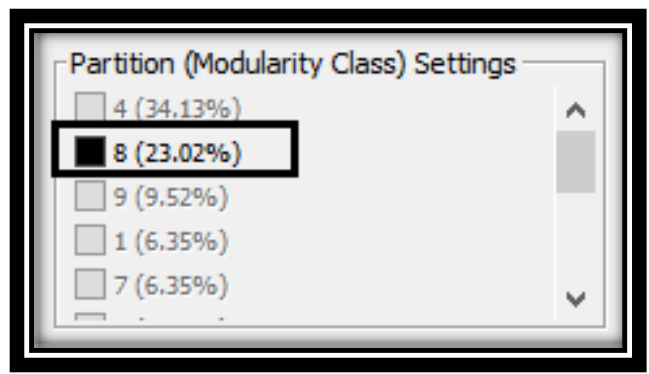

Gambar 31

Gephi Kekuatan Diplomasi Digital antara Indonesia dan Kolombia dengan filter modularity class (node) 


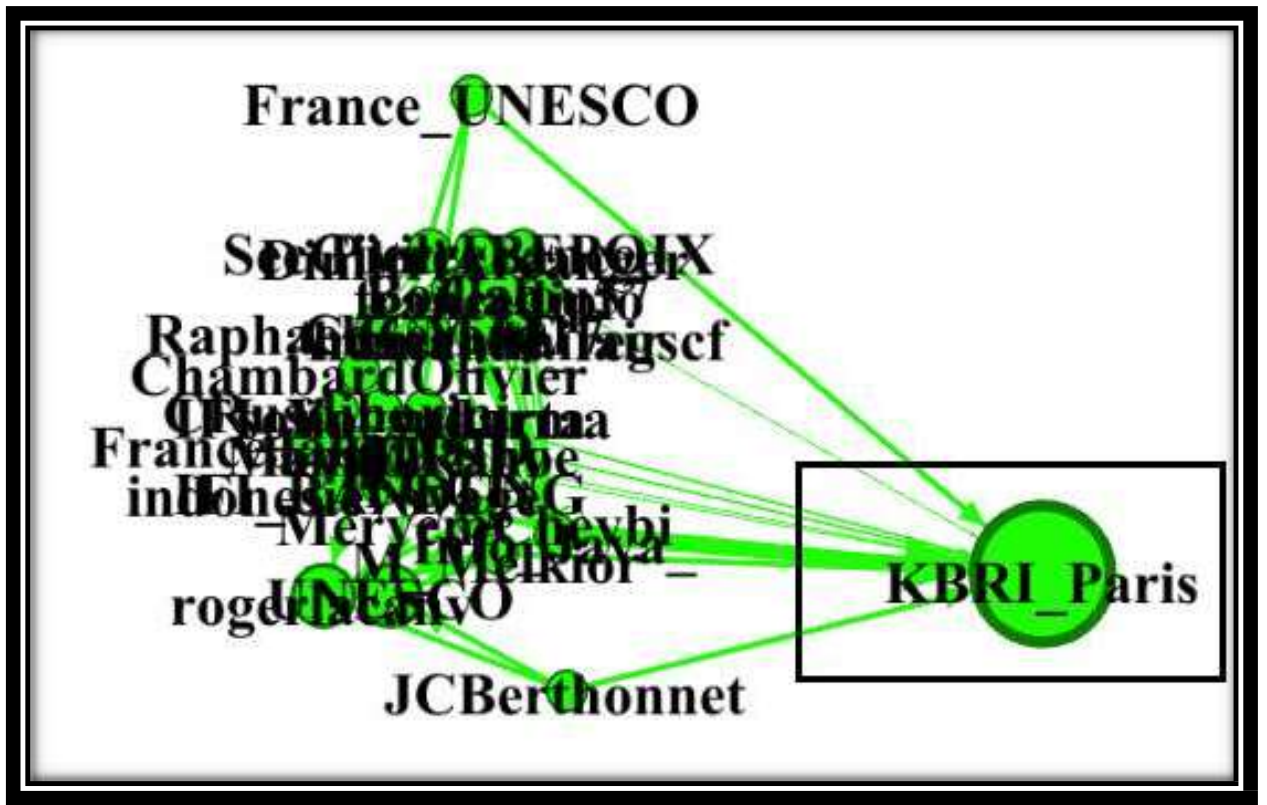

Gambar 32

Gephi Kekuatan Diplomasi Digital antara Indonesia dan French Guiana dengan filter modularity class (node)

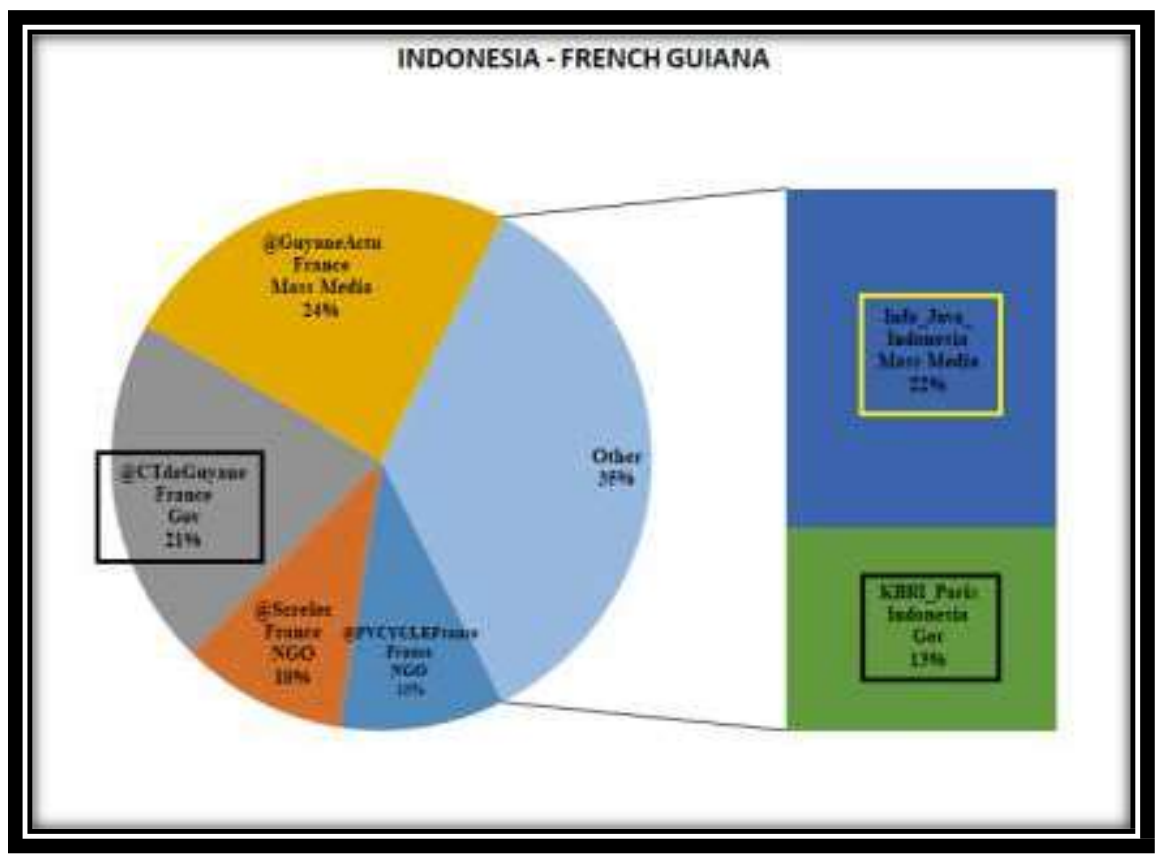

Gambar 33

Data hasil analisa kekuatan diplomasi digital Indonesia dengan Amerika Selatan Dapat disimpulkan bahwa, kekuatan diplomasi digital antara Indonesia dan French Guinia menuai hasil yakni kekuatan diplomasi digital Indonesia masih lemah jika dibanding dengan French Guinia. Dan jika dilihat dari country, Perancis (French Guinia) lebih unggul dalam hal studi kasus diplomasi digital ini. Serta jika dilihat dari cluster, peran pemerintah, NGO dan mass media condong lebih besar pengaruhnya, meskipun aktor yang terlibat atau nodes lebih banyak peran other atau masyarakat digital. Kemudian, country atau parties yang terlibat yakni Perancis, Brazil, Indonesia dan Switzerland.

\section{Guyana}


Penerapan Analisis Jejaring Sosial dalam Mengetahui Kekuatan Diplomasi Digital Indonesia di Kawasan Amerika Selatan

\section{a. Akun Twitter Resmi}

Tidak ada akun twitter resmi untuk Kedutaan Besar Indonesia di Guyana maupun sebaliknya.

\section{Venezuela}

\section{a. Akun Twitter Resmi}

Tidak ada data ketika grabbing data.

$\rightarrow$ @kbri_caracas (Akun twitter Kedutaan Besar Indonesia untuk Venezuela, Republik Trinidad \& Tobago, Grenada, ST. Lucia, Dominika (commonwealth), dan ST. Vincent \& The Grenadines)

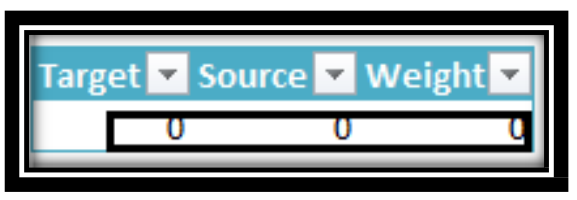

\section{Tabel 22}

Akun twitter tidak aktif, grabbing data kosong

\section{b. Daftar Akun Twitter Resmi yang Tidak Aktif}

1) Daftar Akun Twitter Resmi yang Tidak Aktif

Berikut ialah daftar akun twitter resmi Indonesia dan negara-negara kawasan Amerika Selatan yang tidak aktif.

\begin{tabular}{|c|c|c|c|c|c|c|}
\hline \multirow[b]{2}{*}{ No } & \multirow[b]{2}{*}{ Country } & \multirow[b]{2}{*}{ Coscurrently } & \multicolumn{4}{|c|}{ OFFICIAL TWITIER ACCOUNT } \\
\hline & & & $\begin{array}{l}\text { The Embassy of } \\
\text { Indonesia in Spesific } \\
\text { Country }\end{array}$ & $\begin{array}{l}\text { The Embassy of } \\
\text { Spesific Country in } \\
\text { Indonesia }\end{array}$ & $\begin{array}{l}\text { Consulat General of } \\
\text { Isidonesha is } \\
\text { Spesific Coustry }\end{array}$ & $\begin{array}{l}\text { Consulat General } \\
\text { of Spesific Country } \\
\text { in Indonesia }\end{array}$ \\
\hline & 1 Balivia & Merangkap Perva & kfrilima & + & + & - \\
\hline & $2 \mathrm{Cr}$ e & - & Khrisamiago & - & - & - \\
\hline & 3 Ecuador & 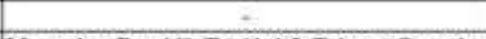 & Quitokhri & + & - & + \\
\hline & 4 Venezuela & $\begin{array}{l}\text { Merangkap Republik Trinidad \& Tobago, Grenada, } \\
\text { ST Luci, Domirika (comanonwealth), dan ST, } \\
\text { Vecent \& The Grenadines }\end{array}$ & Ktri caracas & $=$ & $=$ & + \\
\hline
\end{tabular}

Tabel 23

Daftar Akun Twitter Resmi untuk Diplomasi Digital Indonesia dengan Kawasan Amerika

Selatan yang tidak aktif

2) Daftar Negara Kawasan Amerika Serikat yang Tidak Memiliki Akun Twitter Resmi

Berikut ialah daftar negara-negara kawasan Amerika Selatan yang tidak mempunyai akun twitter resmi.

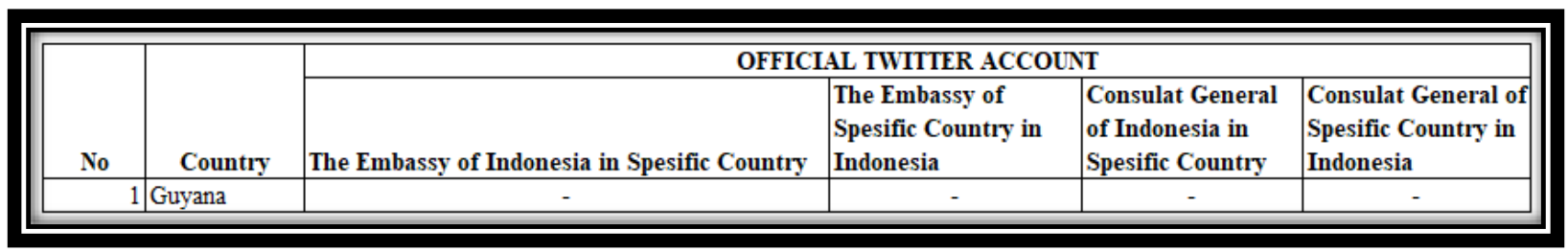

Tabel 24

Daftar Negara untuk Diplomasi Digital Indonesia dengan Kawasan Amerika Selatan yang memiliki akun twitter resmi 


\section{Kesimpulan}

Dengan merujuk pada hasil dari analisa yang dilakukan menggunakan metode social network analysis atau yang disebut sebagai analisa jejaring sosial, serta penggunaan tools gephi 0.9.2 dan microsoft 2016 dalam melakukan penelitian ini, penulis dapat menarik kesimpulan sebagai berikut: 1) Peran Pemerintah dalam studi kasus ini sangatlah penting dan besar, baik dari pihak Iindonesia maupun negara-negara di kawasan Amerika Selatan. 2) Cluster yang mendominasi yakni other atau masyarakat digital meski tidak memiliki pengaruh secara signifikan, pengecualian pada negara Brazil dimana WNI berhasil menempati posisi teratas dalam scoring kekuatan diplomasi digital pada studi kasus ini, sedangkan posisi Indonesia jauh lebih kuat dibanding Brazil. Berbanding terbalik, kekuatan diplomasi Indonesia di kawasan Argentina, Paraguay, dan Kolombia adalah lemah, 3) Kekuatan diplomasi digital Indonesia dengan beberapa negara di kawasan Amerika Selatan juga terkesan lemah bagi kedua pihak, seperti halnya pada negara Bolivia, Peru, Chile dan Ekuador karena akun twitter resmi salah satu atau kedua belah pihak tidak aktif adanya. Sedangkan pada negara Guyana, baik Indonesia maupun Guyana memiliki kesamaan yakni sama-sama tidak memiliki akun twitter resmi terkait diplomasi digital ini.

Indonesia dapat memanfaatkan soft diplomacy yang dapat disalurkan melalui media digital seperti youtube, atau media promosi lainnya, untuk memperkuat kekuatan diplomasi digital Indonesia terutama di kawasan Amerika Selatan. 


\section{Bibliografi}

Britannica. (1998, Juli 20). French Guiana, territorial collectivity, France. Retrieved 11 27, 2020 from Britannica: https://www.britannica.com/place/French-Guiana

Cull, N., \& J. (2009). Public Diplomacy, Lesson from the Past. FIGUEROA PRESS. Los Angeles.

David, B. (2003). The Rise Of Netpolitik. How the Internet Is Changing International Politics and Diplomacy. Washington: The Aspen Institute.

E, O., \& R, R. (2002). Social network analysis: a powerful strategy, also for the information sciences. Journal of Information Science, 28, 443-455.

Eric, E. (2011, Desember 23). ComScore: Google+ Grows Worldwide Users From 65 Million In October To 67 Million In November. (techcrunch) Retrieved 11 27, 2020 from techcrunch:

Haythornthwaite, C. (1996). Ssocial network analysis: an approach and technique for the study of information exchange. LISR, 18, 323-342.

L.C, F. (1979). Centrality in social networks: I. conceptual clarification. Social Networks, 1, 215.

https://techcrunch.com/2011/12/22/googlesplus/?utm_source=feedburner\&utm_medium=fee $\mathrm{d} \& \mathrm{u}$ 